\title{
Novel Autocrine Feedback Control of Catecholamine Release \\ A Discrete Chromogranin A Fragment is a Noncompetitive Nicotinic Cholinergic Antagonist
}

\author{
Sushil K. Mahata, ${ }^{\star}$ Daniel T. O’Connor, ${ }^{\star}$ Manjula Mahata, ${ }^{\star}$ Seung Hyun Yoo, ${ }^{\ddagger}$ Laurent Taupenot, ${ }^{\star}$ Hongjiang Wu, ${ }^{\star}$ Bruce M. Gill, \\ and Robert J. Parmer* \\ *Department of Medicine and Center for Molecular Genetics, University of California, San Diego, California 92093 and Department of \\ Veterans Affairs Medical Center, San Diego, California 92161, and ${ }^{\ddagger}$ National Institute of Deafness and Communicative Disorders, \\ National Institutes of Health, Bethesda, Maryland 20892
}

\begin{abstract}
Catecholamine secretory vesicle core proteins (chromogranins) contain an activity that inhibits catecholamine release, but the identity of the responsible peptide has been elusive. Size-fractionated chromogranins antagonized nicotinic cholinergic-stimulated catecholamine secretion; the inhibitor was enriched in processed chromogranin fragments, and was liberated from purified chromogranin A. Of 15 synthetic peptides spanning $\sim 80 \%$ of chromogranin $A$, one (bovine chromogranin $\mathrm{A}_{344-364}$ [RSMRLSFRARGYGFRGPGLQL], or catestatin) was a potent, dose-dependent ( $\mathrm{IC}_{50}$ $\sim 200 \mathrm{nM}$ ), reversible secretory inhibitor on pheochromocytoma and adrenal chromaffin cells, as well as noradrenergic neurites. An antibody directed against this peptide blocked the inhibitory effect of chromogranin A proteolytic fragments on nicotinic-stimulated catecholamine secretion. This region of chromogranin $\mathrm{A}$ is extensively processed within chromaffin vesicles in vivo. The inhibitory effect was specific for nicotinic cholinergic stimulation of catecholamine release, and was shared by this chromogranin A region from several species. Nicotinic cationic $\left(\mathrm{Na}^{+}, \mathrm{Ca}^{2+}\right)$ signal transduction was specifically disrupted by catestatin. Even highdose nicotine failed to overcome the inhibition, suggesting noncompetitive nicotinic antagonism. This small domain within chromogranin A may contribute to a novel, autocrine, homeostatic (negative-feedback) mechanism controlling catecholamine release from chromaffin cells and neurons. (J. Clin. Invest. 1997. 100:1623-1633.) Key words: chromogranin A - catestatin - acetylcholine - catecholamine $\bullet$ PC12
\end{abstract}

\section{Introduction}

Chromogranin A, an $\sim 48-\mathrm{kD}$ acidic protein initially described in catecholamine storage vesicles of the adrenal medulla $(1,2)$, has a widespread distribution in secretory vesicles throughout the neuroendocrine system $(3,4)$, where it is colocalized and cosecreted with the usual resident peptide or amine hormone $(3,5,6)$. Although the functions of chromogranin A are not

Address correspondence to Daniel T. O'Connor, M.D., Department of Medicine and Center for Molecular Genetics (9111H), University of California, San Diego, 3350 La Jolla Village Drive, San Diego, CA 92161. Phone: 619-552-8585 ext. 7373; FAX: 619-552-7549; E-mail: doconnor@ucsd.edu

Received for publication 11 November 1996 and accepted in revised form 14 July 1997.

The Journal of Clinical Investigation

Volume 100, Number 6, September 1997, 1623-1633

http://www.jci.org completely established, recent evidence implicates chromogranin A as a precursor of several small biologically active secretion-inhibitory peptides that may play an autocrine regulatory role in neuroendocrine secretion from a variety of cell types ( 3 , 7-10). The primary structure of chromogranin A reveals 8-10 conserved pairs of basic amino acids that represent potential proteolytic cleavage sites for the generation of such peptides (11-17), and chromogranin $\mathrm{A}$ is a substrate for the prohormone convertases (18-20).

To date, several chromogranin A-derived peptides have been identified that affect the secretory function of the parent cells. These peptides include: $(a)$ pancreastatin (porcine chromogranin $A_{240-288} ; 21$ ), originally isolated from porcine pancreas, which inhibits glucose-stimulated insulin release from islet $\beta$ cells and parathyroid hormone release from chief cells; (b) the $\mathrm{NH}_{2}$ terminus of chromogranin $\mathrm{A}$, termed $\beta$-granin (rat chromogranin $\mathrm{A}_{1-114} ; 22-24$ ) or vasostatin (human chromogra$\left.\operatorname{nin} \mathrm{A}_{1-76} ; 25,26\right)$, which inhibits parathyroid hormone release and relaxes vascular smooth muscle; and parastatin (porcine chromogranin $\mathrm{A}_{347-419} ; 27$ ), which inhibits parathyroid hormone release.

In 1988 Simon et al. (28) reported that fragmentation of chromogranin A generated peptide(s) that inhibit catecholamine release from cultured adrenal medullary chromaffin cells, but the identity of the responsible peptide has remained elusive (29-31).

In these experiments, we characterized the catecholamine release inhibitory activity in chromogranins, and reproduced it as a potent synthetic fragment of chromogranin A. Our results suggest that this fragment inhibits catecholamine release specifically as a nicotinic cholinergic antagonist, perhaps constituting a novel autocrine secretion regulatory mechanism.

\section{Methods}

Cell culture. Rat PC12 pheochromocytoma cells (32; at passage 8, obtained from Dr. David Schubert, Salk Institute, La Jolla, CA) were grown at $37^{\circ} \mathrm{C} / 6 \% \mathrm{CO}_{2}$ in 10 -cm plates or 6-well plates in DME/high glucose medium supplemented with 5\% FBS, 10\% horse serum, 100 $\mathrm{U} / \mathrm{ml}$ penicillin, and $100 \mu \mathrm{g} / \mathrm{ml}$ streptomycin, as previously described (6).

In some experiments, cells were pretreated with pertussis toxin (100 ng/ml, $16 \mathrm{~h} ; 33$ ).

Bovine adrenal medullary chromaffin cells were prepared and grown in primary culture as previously described (34).

Secretagogue-stimulated norepinephrine release. Norepinephrine secretion was monitored as previously described (35). PC12 cells were plated on poly-D-lysine-coated polystyrene dishes (Falcon Labware, Oxnard, CA), labeled for $3 \mathrm{~h}$ with $1 \mu \mathrm{Ci}\left[{ }^{3} \mathrm{H}\right] \mathrm{L}$-norepinephrine (71.7 Ci/mmol, DuPont-NEN, Boston, MA) in $1 \mathrm{ml}$ of PC12 growth medium, washed twice with release buffer $(150 \mathrm{mM} \mathrm{NaCl}, 5 \mathrm{mM} \mathrm{KCl}, 2$

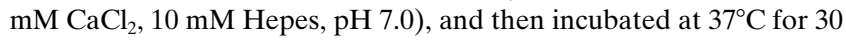
min in release buffer with or without secretagogues, such as nicotine $(60 \mu \mathrm{M})$, or cell membrane depolarization $(55 \mathrm{mM} \mathrm{KCl})$. Release buffer for experiments involving $\mathrm{KCl}$ as secretagogue had $\mathrm{NaCl}$ re- 
duced to $100 \mathrm{mM}$ to maintain isotonicity. After $30 \mathrm{~min}$, secretion was terminated by aspirating the release buffer, and by lysing cells into

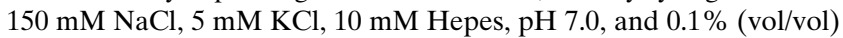
Triton X-100. Release medium and cell lysates were assayed for $\left[{ }^{3} \mathrm{H}\right]$ norepinephrine by liquid scintillation counting, and results were expressed as percent secretion (amount released/[amount released + amount in cell lysate]) $\times 100$. Net secretion is secretagoue-stimulated release minus basal release, where basal norepinephrine release is typically $5.8 \pm 0.36 \%$ of cell total $\left[{ }^{3} \mathrm{H}\right]$ norepinephrine released over 30 $\min (n=10$ separate secretion assays).

Chromogranin size fractions. Bovine adrenal medullary chromaffin granules were prepared by differential and sucrose step gradient centrifugation, as previously described (36). Granules were lysed into $1 \mathrm{mM} \mathrm{Na}$ Hepes, $\mathrm{pH} 7.0$, and the membranes were pelleted at $100,000 \mathrm{~g}$ for $1 \mathrm{~h}$. Soluble core contents were size-fractionated at $4{ }^{\circ} \mathrm{C}$ on a $2.5 \times$ $80-\mathrm{cm}$ column of Sephacryl S-300, and were equilibrated and eluted with $0.3 \mathrm{M}$ ammonium acetate, $\mathrm{pH} 6.5$, at $37 \mathrm{ml} / \mathrm{h}$ (37). 6- $\mathrm{ml}$ fractions were analyzed by SDS-PAGE and staining with Coomassie blue, and then high and low molecular weight protein fractions were pooled, lyophilized (twice, to remove the volatile ammonium acetate buffer), and resuspended in $1 \mathrm{mM}$ Na Hepes, $\mathrm{pH}$ 7.0. Protein concentrations were determined by the Coomassie blue dye-binding technique (38).

Low molecular weight chromogranin fractions (not containing chromogranin A on SDS-PAGE) were further purified and concentrated by solid phase extraction onto a Sep-Pak classic C-18 silica cartridge (Waters-Millipore, Milford, MA). The cartridge was first washed with $0.1 \%$ trifluoroacetic acid (TFA) ${ }^{1}$ in water, activated with $80 \% \mathrm{CH}_{3} \mathrm{CN} / 20 \% \mathrm{H}_{2} \mathrm{O} / 0.1 \% \mathrm{TFA}$, and then equilibrated in $0.1 \%$ TFA in water. Peptides were adsorbed to the cartridge in $0.1 \%$ TFA in water. The column was washed with $0.1 \%$ TFA in water, and the peptides were eluted with $80 \% \mathrm{CH}_{3} \mathrm{CN} / 20 \% \mathrm{H}_{2} \mathrm{O} / 0.1 \%$ TFA, lyophilized (SpeedVac; Savant Instruments Inc., Farmingdale, NY), and resuspended in water.

Chromogranin A. Bovine or human chromogranin A was isolated from chromaffin granule soluble core proteins by affinity chromatography (to remove dopamine $\beta$-hydroxylase) followed by gel filtration, as previously described (37). In some experiments, chromogranin A was allowed to undergo proteolysis in the extracellular space (in growth medium minus serum) by addition to secretion medium-washed PC12 cells; after an 18-h (overnight) incubation at $37^{\circ} \mathrm{C}$, the medium was collected, and 5 vols of acetone $\left(\right.$ at $-20^{\circ} \mathrm{C}$ ) were added to precipitate proteins and peptides while small molecules (such as catecholamines and ATP) remained in the supernate. After vortexing and precipitation overnight at $-20^{\circ} \mathrm{C}$, the precipitate was collected by centrifugation $\left(13,000 \mathrm{~g}, 10 \mathrm{~min}, 4^{\circ} \mathrm{C}\right)$, whereupon the supernate was aspirated, and the pellet was vacuum-dried (Savant Instruments, Inc.) and resuspended in $1 \mathrm{mM} \mathrm{Na}$ Hepes, $\mathrm{pH}$ 7.0.

Synthetic peptides. Chromogranin A peptides were synthesized at 10-100 $\mu \mathrm{mol}$ scale by the solid-phase method (39) using t-boc or f-moc protection chemistry, and were then purified to $>95 \%$ homogeneity by reversed phase high pressure liquid chromatography on C-18 silica columns, monitoring $\mathrm{A}_{280}$ (aromatic rings) or $\mathrm{A}_{214}$ (peptide bonds). Authenticity and purity of peptides were verified by rechromatography, as well as electrospray-ionization or MALDI mass spectrometry, or amino acid composition. Substance P (RPKPQQFFGLM-amide), or the potent substance $\mathrm{P}$ receptor antagonist Boc-Gln-D-Trp(CHO)-Phe-OBzl (40), was obtained from Peninsula Laboratories, Inc. (Belmont, CA). Boc-Gln-D-Trp(CHO)-Phe-OBzl inhibits $\left[{ }^{3} \mathrm{H}\right]$ substance $\mathrm{P}$ binding to guinea pig lung membranes, with $\mathrm{IC}_{50}=$ $9 \mathrm{nM}(40)$.

Immunoblotting. Polyclonal rabbit antisera recognizing bovine catestatin (RSMRLSFRARGYGFRGPGLQL) were developed by a modification of protocols previously described for other chromogranin peptides $(41,42)$.

Chromaffin granules were prepared from homogenates of freshly

1. Abbreviation used in this paper: TFA, trifluoroacetic acid. obtained bovine adrenal medullae, on $0.3 \mathrm{M} / 1.6 \mathrm{M}$ sucrose density step-gradients, as previously described $(41,43)$, then lysed in $1 \mathrm{mM}$ $\mathrm{NaH}_{2} \mathrm{PO}_{4}, \mathrm{pH} 6.5$, and centrifuged at $100,000 \times g$ for $60 \mathrm{~min}$ to remove granule membranes. The vesicle soluble core proteins (chromogranins; $10 \mu \mathrm{g} /$ lane) were electrophoresed through Tris-Tricine (16.5-10\%) SDS-PAGE slab gels, transferred to nitrocellulose sheets, and visualized with amido black protein stain, or with rabbit antibovine catestatin (1:500, vol:vol), followed by horseradish peroxidaselabeled second antibody, and enhanced chemiluminescence detection (ECL, Amersham Corp., Arlington Heights, IL).

Neuronal differentiation of PC12 cells with nerve growth factor. PC12 cells were split to $50 \%$ confluence and treated with nerve growth factor $(2.5 \mathrm{~S}$ form, $100 \mathrm{ng} / \mathrm{ml}$; Boehringer-Mannheim, Indianapolis, IN). The medium was changed every other day, with nerve growth factor addition to the new medium. After $5 \mathrm{~d}$ of treatment, the neurite-bearing cells were used for secretion studies as described above.

${ }^{22} \mathrm{Na}^{+}$uptake by PC12 cells. ${ }^{22} \mathrm{Na}^{+}$uptake was performed as described by Amy and Kirshner (44) with minor modifications. Before experiments, PC12 cells were washed twice with $50 \mathrm{mM} \mathrm{Na}^{+}$-sucrose media containing $50 \mathrm{mM} \mathrm{NaCl}, 187 \mathrm{mM}$ sucrose, $5 \mathrm{mM} \mathrm{KCl}, 2 \mathrm{mM}$ $\mathrm{CaCl}_{2}$, and $5 \mathrm{mM}$ Hepes adjusted to $\mathrm{pH} 7.4$ with $\mathrm{NaOH}$. To measure ${ }^{22} \mathrm{Na}^{+}$influx, this medium was then supplemented with $5 \mathrm{mM}$ ouabain (to prevent active extrusion of newly taken up ${ }^{22} \mathrm{Na}^{+}$from cells) and $1.5 \mu \mathrm{Ci} / \mathrm{ml}$ of ${ }^{22} \mathrm{NaCl}$. Incubation was carried out at $22^{\circ} \mathrm{C}$ for $5 \mathrm{~min}$ in the presence or absence of secretagogues, and then the cells were washed within $10 \mathrm{~s}$ with three changes $\left(1 \mathrm{ml}\right.$ each) of $50 \mathrm{mM} \mathrm{Na}^{+}$ sucrose media with $5 \mathrm{mM}$ ouabain. The cells were lysed (see above), and ${ }^{22} \mathrm{Na}^{+}$in the cell lysate was measured in a $\gamma$ counter (LKB 1274 RIAGAMMA; Wallac Inc., Gaithersburg, MD). The data were expressed as dpm/well.

${ }^{45} \mathrm{Ca}^{2+}$ uptake by PC12 cells. Cells were seeded onto poly-Dlysine-coated six-well polystyrene culture dishes $2 \mathrm{~d}$ before assay. Cells were rinsed with $1 \mathrm{ml}$ of release buffer, and were preincubated with $1 \mathrm{ml}$ of release buffer for $30 \mathrm{~min}$ at $37^{\circ} \mathrm{C}$. Then the cells were incubated for $5 \mathrm{~min}$ at $37^{\circ} \mathrm{C}$ in $1 \mathrm{ml}$ of release buffer (without unlabeled calcium) containing $2 \mu \mathrm{Ci}$ of ${ }^{45} \mathrm{Ca}^{2+}(14.95 \mathrm{mCi} / \mathrm{mg}$; DuPont/NEN). The drugs tested were present in the release buffer during the 1-min incubation period. Calcium uptake was stopped abruptly after 1 min by inversion of the plate to decant all six wells simultaneously, followed promptly by addition of $2 \mathrm{ml}$ of ice-cold release buffer containing $1 \mathrm{mM} \mathrm{LaCl}$; the nonselective calcium channel blocker $\mathrm{La}^{3+}$ terminates further uptake of extracellular labeled calcium (45). The culture dishes were then rinsed twice with ice-cold release buffer. To cells in each well, $1 \mathrm{ml}$ of cell lysis buffer was added and collected for liquid scintillation counting. The data were expressed as dpm/well.

Imaging cytosolic $\mathrm{Ca}^{2+}$. Single-cell $\left[\mathrm{Ca}^{2+}\right]_{\mathrm{i}}$ assays were performed using the fluorescent $\mathrm{Ca}^{2+}$ indicator Indo 1-AM (Molecular Probes, Inc., Eugene, OR), as previously described (46). Bovine adrenal chromaffin cells grown on glass coverslips were placed in an observation chamber and washed twice with Locke's solution $(140 \mathrm{mM} \mathrm{NaCl}, 4.7$ $\mathrm{mM} \mathrm{KCl}, 2.5 \mathrm{mM} \mathrm{CaCl}_{2}, 1.2 \mathrm{mM} \mathrm{MgCl}, 1.2 \mathrm{mM} \mathrm{KH}_{2} \mathrm{PO}_{4}, 10 \mu \mathrm{M}$ EDTA, $11 \mathrm{mM}$ glucose, $0.56 \mathrm{mM}$ ascorbic acid, and $15 \mathrm{mM}$ Hepes, $\mathrm{pH}$ 7.4). Cells were loaded by incubation with $5 \mu \mathrm{M}$ Indo $1 / \mathrm{AM}$ and $0.02 \%$ Pluronic F127 (Molecular Probes, Inc.) in Locke's solution for $30 \mathrm{~min}$ at $37^{\circ} \mathrm{C}$. Cells were washed twice with Locke's solution and left in the dark for $30 \mathrm{~min}$ before fluorescence measurements. Fluorescence from single cells was determined with a Diaphot inverted microscope (Nikon Inc., Melville, NY) fitted for dual emission microspectrofluorimetry. The excitation wavelength was $355 \mathrm{~nm}$, and emission was simultaneously recorded at 405 and $480 \mathrm{~nm}$ (yielding $\mathrm{F}_{405}$ and $\mathrm{F}_{480}$ ). The ratio $\mathrm{F}_{405} / \mathrm{F}_{480}$, representing variations in cytosolic $\left[\mathrm{Ca}^{2+}\right]_{\mathrm{i}}$, was recorded online as a voltage signal, and analyzed using a MacLab System (AD Instruments Pty Ltd, Castle Hill, Australia). Synthetic bovine catestatin (chromogranin $\mathrm{A}_{344-364}$ ) was added to the incubation medium $10 \mathrm{~min}$ before stimulation. Single bovine chromaffin cells were then stimulated for $5 \mathrm{~s}$ with nicotine $(10-50 \mu \mathrm{M}$ in Locke's solution) applied with a Femtotips pipette (Eppendorf, Ham- 
A

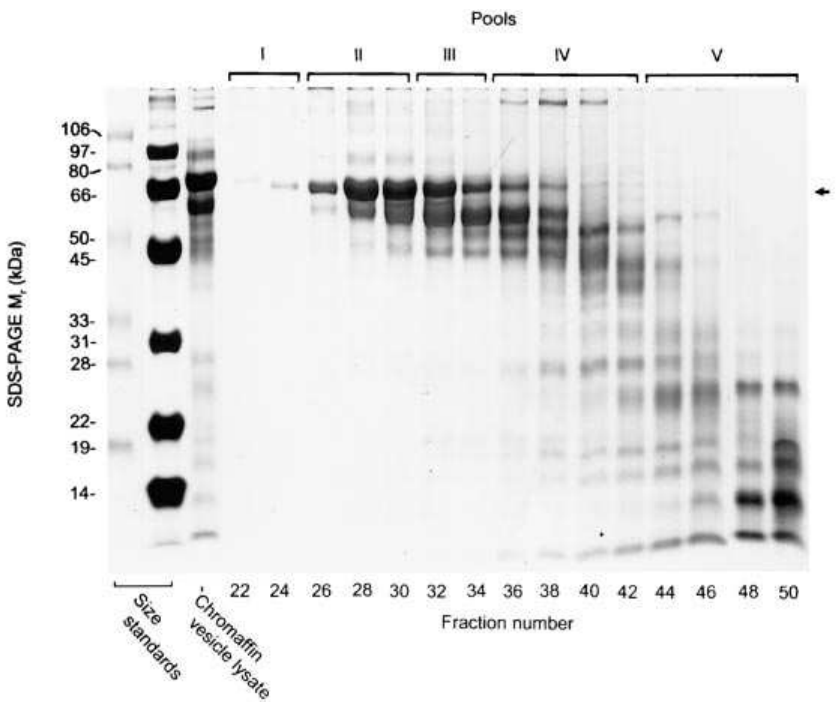

B

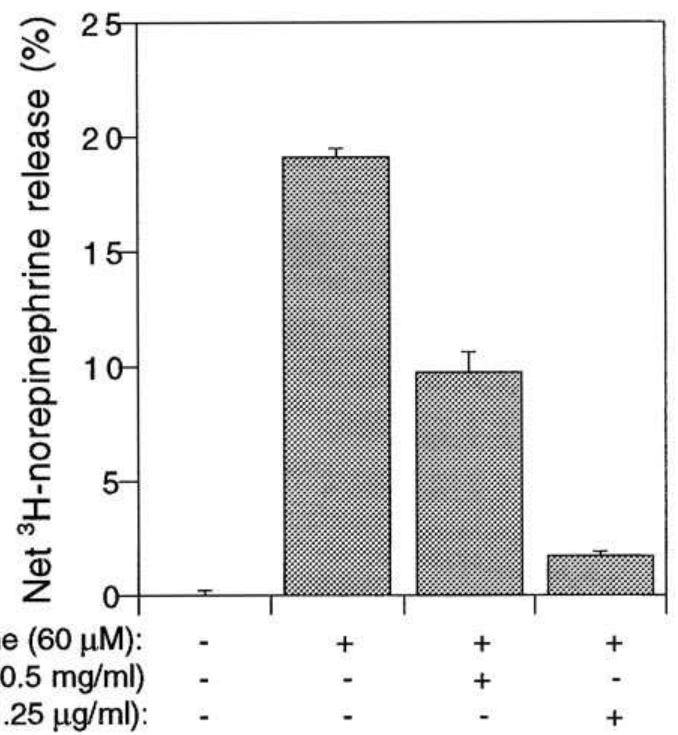

C

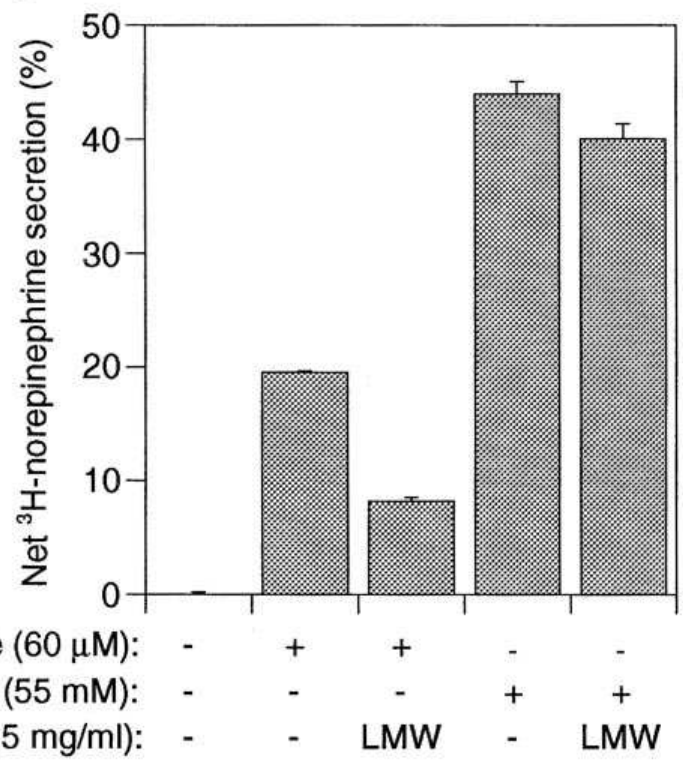

D

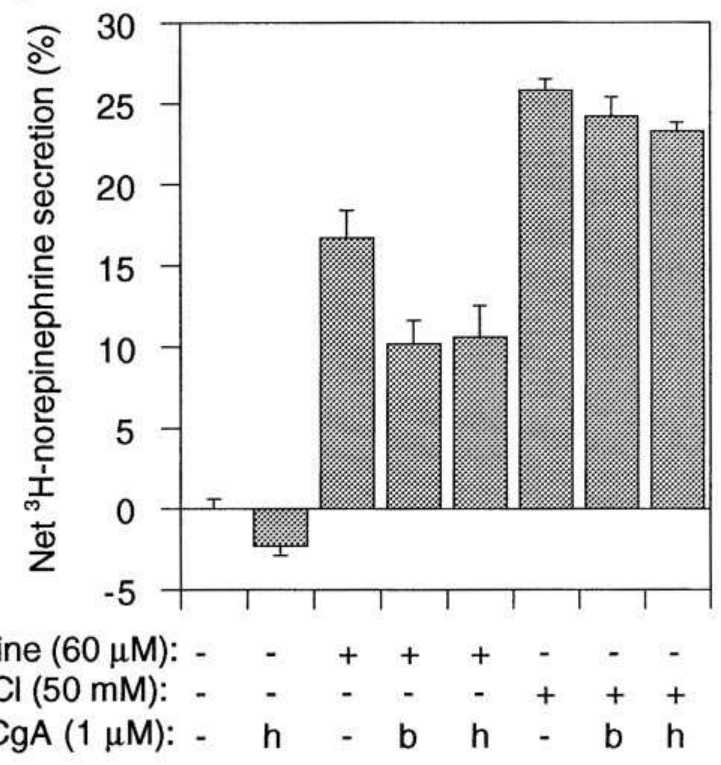

Figure 1. Role of chromogranins or chromogranin A on secretagogue-induced norepinephrine release. (A) Size fractionation of chromogranins (bovine adrenal medullary chromaffin granule soluble core proteins) by gel filtration on a $2.6 \times 80-\mathrm{cm}$ column of Sephacryl S-300, equilibrated and eluted at $37 \mathrm{ml} / \mathrm{h}\left(4^{\circ} \mathrm{C}\right)$ with the volatile buffer $0.3 \mathrm{M}$ ammonium acetate, $\mathrm{pH}$ 6.5. Eluted 6-ml fractions were analyzed by SDS-PAGE (30 $\mu \mathrm{g}$ protein/lane) and pooled into molecular weight groups, lyophilized twice, and resuspended in $1 \mathrm{mM}$ Na Hepes, pH 7.0. Fractions I-III were high molecular weight (HMW) chromogranins, containing intact chromogranin A. Fraction V, low molecular weight chromogranins, was devoid of intact chomogranin A. Fraction IV was not further used in these studies. The arrowhead indicates the position of chromogranin A. (B) Effect of high versus low molecular weight chromogranin gel filtration fragments on catecholamine secretion in response to nicotinic cholinergic stimulation. PC12 cells were prelabeled with [ $\left.{ }^{3} \mathrm{H}\right] \mathrm{L}$-norepinephrine, and were then treated with $60 \mu \mathrm{M}$ nicotine, with or without high or low molecular chromogranins $(0.5 \mathrm{mg} / \mathrm{ml}$ corresponds to $\sim 10 \mu \mathrm{M}$ chromogranin A), and harvested after $30 \mathrm{~min}$ for measurement of norepinephrine secretion. LMW, low molecular weight; Cgs, chromogranins. In this experiment, the LMW chromogranins were further purified after gel filtration by solid phase extraction (see Methods). (C) Effect of low molecular weight chromogranin gel filtration fragments on catecholamine release: comparison of effects on nicotinic versus membrane depolarization stimuli. PC12 cells were prelabeled with $\left[{ }^{3} \mathrm{H}\right] \mathrm{L}$-norepinephrine, and were then treated with either nicotine $(60 \mu \mathrm{M})$ or $\mathrm{KCl}(55 \mathrm{mM})$, with or without low molecular weight chromogranin fragments $(0.5 \mathrm{mg} / \mathrm{ml}$ corresponds to $\sim 10$ $\mu \mathrm{M}$ chromogranin $\mathrm{A}$ ), and harvested after $30 \mathrm{~min}$ for measurement of norepinephrine secretion. In this experiment, the LMW chromogranins were isolated only by gel filtration, without a subsequent solid phase extraction step. $(D)$ Effect of chromogranin A fragments (generated by extracellular proteolysis on PC12 cells) on catecholamine secretion. Purified bovine or human chromogranin A were preincubated with PC12 cells in monolayer culture in serum-free medium for $18 \mathrm{~h}$, after which proteolytic fragments of chromogranin A were precipitated from the medium by acetone $\left(80 \%\right.$ acetone, $-20^{\circ} \mathrm{C}$, overnight), dried and resuspended. The effect of these chromogranin A fragments $(1 \mu \mathrm{M})$ on PC12 catecholamine secretion was then evaluated, with exocytotic secretion triggered by nicotinic $(60 \mu \mathrm{M})$ stimulation, versus membrane depolarization $(50$ $\mathrm{mM} \mathrm{KCl})$. CgA, chromogranin A; h, human; b, bovine. 
burg, Germany) positioned near the cell, using an Eppendorf 3-D motorized micromanipulator.

\section{Results}

Search for and identification of the catecholamine release-inhibitory chromogranin A peptide (or catestatin). Both high and low molecular weight bovine chromaffin granule core (chromogranin/secretogranin) protein/peptide fractions (Fig. $1 \mathrm{~A}$; at $0.5 \mathrm{mg} / \mathrm{ml}$, corresponding to $\sim 10 \mu \mathrm{M}$ chromogranin A $[13,14$, 47]) significantly inhibited nicotine-stimulated norepinephrine release from PC12 cells, while the lower molecular weight fraction appeared to be even more active at far lesser mass $(1.25$ $\mu \mathrm{g} / \mathrm{ml}$ ) (Fig. $1 B$ ).

The low molecular weight chromogranin fraction substantially inhibited catecholamine release when triggered by nicotinic cholinergic stimulation $(60 \mu \mathrm{M}$ nicotine $)$, though it had no significant effect on secretion triggered by membrane depolarization $(55 \mathrm{mM} \mathrm{KCl})$, which opens voltage-gated calcium channels (Fig. $1 C$ ). Thus, the crude low molecular weight peptides apparently contained a secretion inhibitor specific for nicotinic cholinergic stimulation.

To see whether chromogranin A itself, or its fragments, exert a secretion-inhibitory effect on nicotine-induced norepinephrine release, we preincubated purified bovine or human chromogranin A with PC12 cells for $18 \mathrm{~h}$, and then acetone- precipitated the chromogranin A fragments generated in the extracellular space (precipitation to remove secreted small molecules such as catecholamines or ATP). Norepinephrine secretion was studied using nicotine $(60 \mu \mathrm{M})$ or $\mathrm{KCl}(55 \mathrm{mM}$; to depolarize the cell membrane) as secretagogues, in the presence or absence of these chromogranin A fragments $(1 \mu \mathrm{M})$. Once again, chromogranin $\mathrm{A}$ fragments inhibited secretion of norepinephrine when triggered by nicotine, though not by membrane depolarization (Fig. $1 D$ ). By contrast, when intact $1 \mu \mathrm{M}$ chromogranin A was coapplied with $60 \mu \mathrm{M}$ nicotine onto PC12 cells, nicotinic-stimulated norepinephrine secretion was only marginally inhibited: in one experiment, nicotinicstimulated norepinephrine secretion of $19.2 \pm 0.6 \%$ of cell total declined to $16.6 \pm 0.1 \%$ with coapplication of intact $1 \mu \mathrm{M}$ chromogranin A $(P=0.007)$; in another experiment, nicotinicstimulated norepinephrine release $(13.1 \pm 1.4 \%)$ was unaltered by coapplication of intact $1 \mu \mathrm{M}$ chromogranin A $(12.5 \pm 1.4 \%)$.

In search of the specific secretion-inhibitory domain within chromogranin A, we synthesized 15 peptides (average length, 22 residues; range, 19-25 residues) spanning 336 amino acids, or $78 \%$ of the length of the bovine chromogranin A 431 amino acid mature protein, and then tested their efficacies on nicotine-induced norepinephrine secretion, screening the peptides at $10 \mu \mathrm{M}$ concentration. Only bovine chromogranin $\mathrm{A}_{344-364}$ (RSMRLSFRARGYGFRGPGLQL) significantly decreased nicotine-induced secretion of norepinephrine, but the reduc-
A.

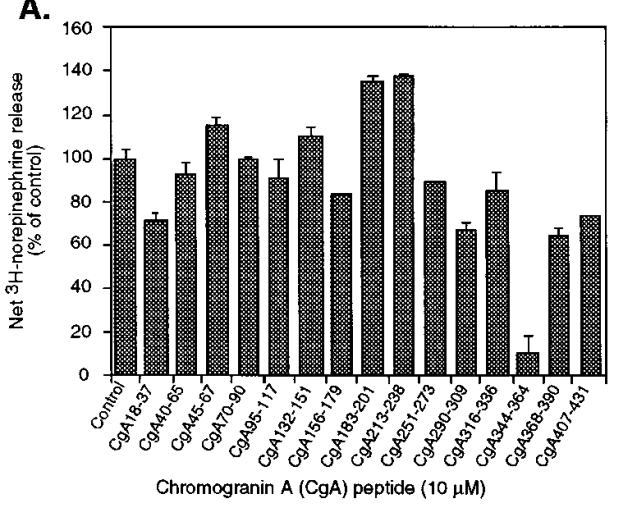

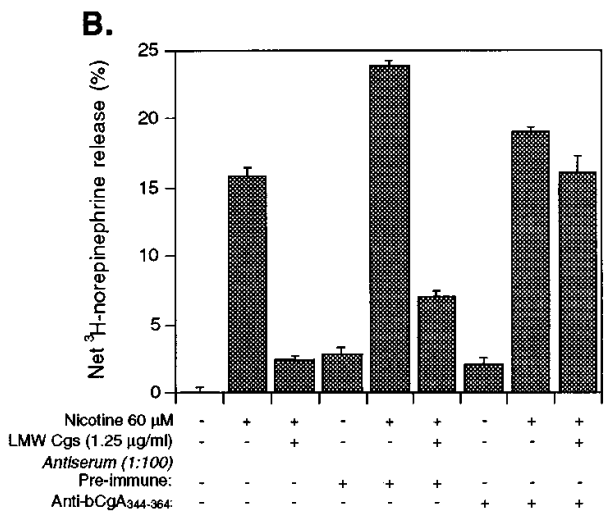

c.

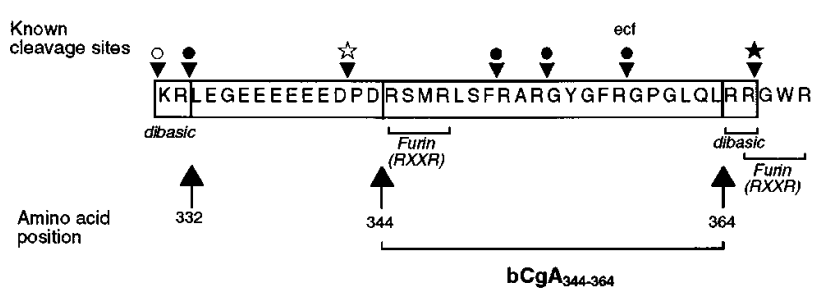

Figure 2. Identification and characterization of the catecholamine secretion-inhibitory chromogranin A fragment peptide, catestatin. $(A)$ Inhibitory effect of a series of chromogranin A synthetic peptides scanning the molecule. PC12 cells were prelabeled with $\left[{ }^{3} \mathrm{H}\right] \mathrm{L}$-norepinephrine, and were then treated with $60 \mu \mathrm{M}$ nicotine, either alone or in the presence of a chromogranin A synthetic peptide $(10 \mu \mathrm{M})$, and were harvested after $30 \mathrm{~min}$ for norepinephrine secretion measurement. Control (100\%) net norepinephrine release is that in the presence of nicotine $(60 \mu \mathrm{M})$ stimulation alone, without peptide. $(B)$ Inhibition of nicotinic-stimulated catecholamine release by low molecular weight (LMW) chromogranin gel filtration fragments: reversal by an antiserum directed against catestatin. LMW bovine chromogranin gel filtration fragments were preincubated $\left(4^{\circ} \mathrm{C}\right.$, overnight) with either a rabbit antiserum directed against the bovine catestatin sequence (RSMRLSFRARGYGFRGPGLQL; bovine

chromogranin $\mathrm{A}_{344-364}$ ), or preimmune serum, each at 1:100 (vol/vol) dilution. Catecholamine release was then triggered from PC12 cells by nicotine $(60 \mu \mathrm{M})$, in the presence or absence of these LMW chromogranin fragments. $(C)$ Documented sites of proteolytic cleavage in the catestatin region of bovine chromogranin A (bovine chromogranin $\mathrm{A}_{344-364}$ ). At the $\mathrm{NH}_{2}$ and $\mathrm{COOH}$ termini are furin recognition sites (RXXR), while a dibasic site (RR) is at the $\mathrm{COOH}$ terminus. The citations and symbols above and below the chromogranin A primary structure are reports documenting specific cleavages at that particular site, usually determined by microsequencing of separated chromaffin granule peptides. Filled triangles, cleavage site; filled-circles, Metz-Boutigue et al. (7); open circles, Curry et al. (48a); filled star, Kirchmair et al. (48b); open star, Sigafoos et al. (48c). ecf, cleavage in extracellular space; bCgA, bovine chromogranin A, Cgs, chromogranins. 


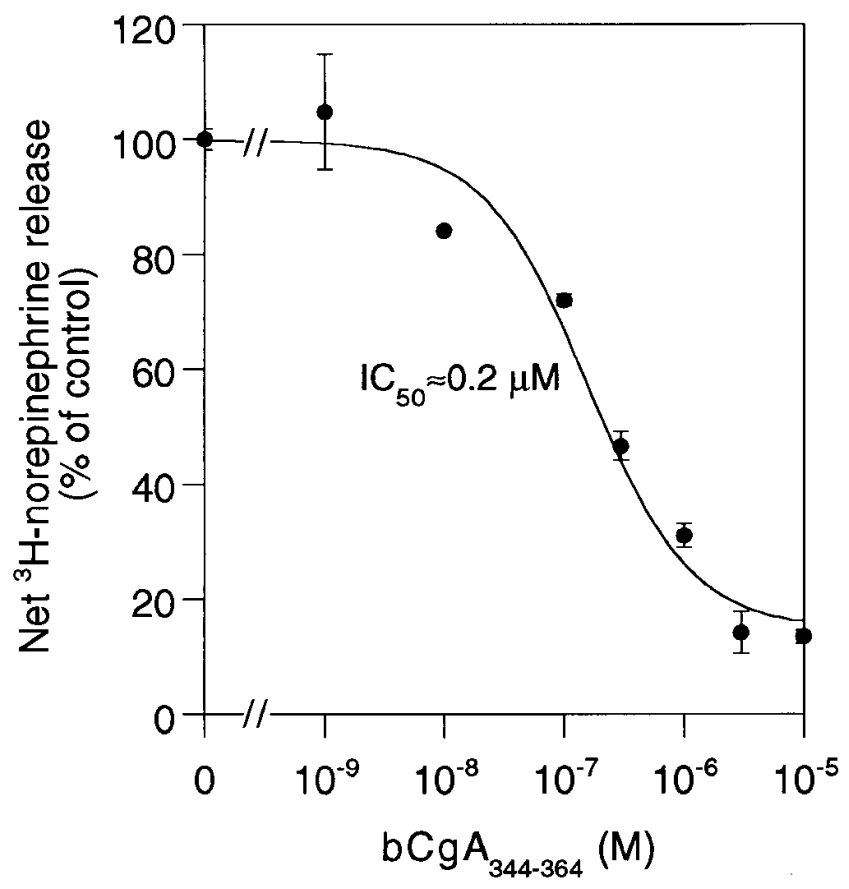

Figure 3. Potency of catecholamine secretion inhibition by catestatin (bovine chromogranin $\mathrm{A}_{344-364}$ [RSMRLSFRARGYGFRGPGLQL]). Catestatin dose-response curve. $\left[{ }^{3} \mathrm{H}\right] \mathrm{L}$-norepinephrine-prelabeled cells were incubated with $60 \mu \mathrm{M}$ nicotine, with or without different doses $(0.01-10 \mu \mathrm{M})$ of bovine catestatin for $30 \mathrm{~min}$. Control $(100 \%)$ net norepinephrine release is that in the presence of nicotine $(60 \mu \mathrm{M})$ stimulation alone, without catestatin. bCgA, bovine chromogranin A

tion was profound (over $90 \%$ loss of stimulated secretion at $10 \mu \mathrm{M}$ peptide; Fig. $2 A$ ). Because the peptide inhibits catecholamine release, it was named catestatin.

An antiserum directed against this peptide (RSMRLSFRARGYGFRGPGLQL) almost completely reversed the ability of low molecular weight chromogranin gel filtration fragments to inhibit nicotinic-stimulated catecholamine release (Fig. $2 \mathrm{~B}$ ), while the inhibition was largely unaffected by preimmune serum.

Proteolytic processing of the catestatin region from chromogranin A. The catestatin region in bovine chromogranin A is bounded by furin recognition sites, RXXR (48), at its $\mathrm{NH}_{2}$ and $\mathrm{COOH}$ termini, and a dibasic site, $\mathrm{RR}$, at its $\mathrm{COOH}$ terminus (Fig. 2 C). There are a variety of previously documented proteolytic cleavages in this region (Fig. 2 C, 48 a-c).

Immunoblotting of bovine chromaffin granule soluble core proteins with an antibody directed against synthetic catestatin shows extensive processing of this region, with generation of low molecular weight immunoreactive chromogranin A fragments bearing catestatin epitopes (data not shown).

Potency of catecholamine secretion inhibition by catestatin. Bovine catestatin displayed dose-dependent inhibition of nicotine-stimulated catecholamine secretion from PC12 cells, and its $\mathrm{IC}_{50}$ was $\sim 200 \mathrm{nM}$ (Fig. 3).

Bovine catestatin equivalently inhibited nicotinic-stimulated catecholamine secretion, whether administered to PC12 cells well before or simultaneously with nicotine (data not shown). Its effects were completely and specifically abolished by proteolytic digestion with pronase $(0.1 \mathrm{mg} / \mathrm{ml}, 30 \mathrm{~min}$; data not shown), indicating that the secretion-inhibitory activity of catestatin resides in its peptide structure. The peptide's action was heat-stable (unaffected by boiling for $10 \mathrm{~min}$ before use; data not shown).

Catestatin effects across species and across catecholaminergic cell types. Bovine catestatin (bovine chromogranin $\mathrm{A}_{344-364}$ ) inhibited nicotine-induced norepinephrine release from both the rat $\mathrm{PC} 12$ pheochromocytoma cell line and primary cultures of bovine adrenal chromaffin cells (Fig. $4 A$ ).

When PC12 cells were differentiated to a neurite-bearing morphology with nerve growth factor $(100 \mathrm{ng} / \mathrm{ml}, 5 \mathrm{~d})$, bovine catestatin also inhibited nicotine-induced secretion of norepinephrine, though with a somewhat higher $\operatorname{IC}_{50}(\sim 2.01 \mu \mathrm{M})$ (Fig. $4 B$ ).

Table I shows the sequence homology of the catestatin region across the several mammalian species whose chromogranin A primary structures are known (bovine [11, 12], human $[13,14]$, rat [15, 49], murine [17], and porcine [16]). The sequence is highly conserved, with most residues identical or conservative substitutions.

The effects of synthetic bovine (bovine chromogranin A $_{344-364}$; RSMRLSFRARGYGFRGPGLQL), human (human chromogranin A $_{352-372}$; SSMKLSFRARAYGFRGPGPQL), or rat (rat chromogranin $\mathrm{A}_{367-387}$; RSMKLSFRARAYGFRDPG$\mathrm{PQL})$ catestatins were tested on nicotine-induced norepinephrine release from rat PC12 cells (Fig. 4 C). Each species' form of catestatin suppressed nicotine-induced norepinephrine release, though the bovine form had the greatest potency (lowest $\left.\mathrm{IC}_{50}\right)$.

Catestatin inhibition specific for nicotinic cholinergic stimulation of catecholamine secretion. In addition to stimulation of the physiologic (nicotinic cholinergic) secretory pathway (by nicotine, $60 \mu \mathrm{M}$ ), we tested several secretagogues that act at stages in the pathway later than the nicotinic receptor (Table II), including membrane depolarization $(55 \mathrm{mM} \mathrm{KCl})$ to open voltage-gated calcium channels, an alkaline earth $\left(\mathrm{BaCh}_{2}, 2 \mathrm{mM}\right.$; whose effects require participation of calcium channels), a calcium ionophore (A23187, $1 \mu \mathrm{M})$, or alkalinization of the chromaffin vesicle core (chloroquine, $1 \mathrm{mM}$ ). The results show that bovine catestatin suppressed norepinephrine release only when triggered by nicotine (Table II), and not when secretion was caused by agents acting later (i.e., distal to the nicotinic cholinergic receptor) in the secretory pathway.

Stimulation of $\mathrm{P}_{2 \mathrm{x}}$ purinergic receptors causes catecholamine secretion from PC12 cells (50-52). Since $\mathrm{P}_{2 \mathrm{x}}$ purinergic receptors and nicotinic cholinergic receptors are members of the same superfamily of extracellular ligand-gated cation channels (52), we tested the effect of bovine catestatin on the function of this receptor as well. Although the somewhat selective $\mathrm{P}_{2 \mathrm{x}}$ antagonist reactive blue $2(50,52)$ partially inhibited ATPstimulated catecholamine release, catestatin was without effect on this ligand-receptor system (Table II).

To test whether bovine catestatin's effect on nicotine-induced norepinephrine release is mediated by inhibitory G-proteins, we pretreated PC12 cells with pertussis toxin $(100 \mathrm{ng} / \mathrm{ml}, 16 \mathrm{~h}$ [33]); no effect of pertussis toxin was found (data not shown).

Catestatin and nicotinic cholinergic signal transduction: $\mathrm{Na}^{+}$ and $\mathrm{Ca}^{2+}$ cation fluxes. Bovine catestatin blocked nicotineinduced uptake of ${ }^{22} \mathrm{Na}^{+}$into PC12 cells (Fig. $5 A$ ); the blockade was dose-dependent (Fig. $5 A$ ), and paralleled blockade of catecholamine release (Fig. 3); $\mathrm{IC}_{50}$ values for inhibition of both catecholamine secretion (Fig. 3) and ${ }^{22} \mathrm{Na}^{+}$uptake (Fig. 5 $A)$ were similar $(\sim 200-250 \mathrm{nM})$. 

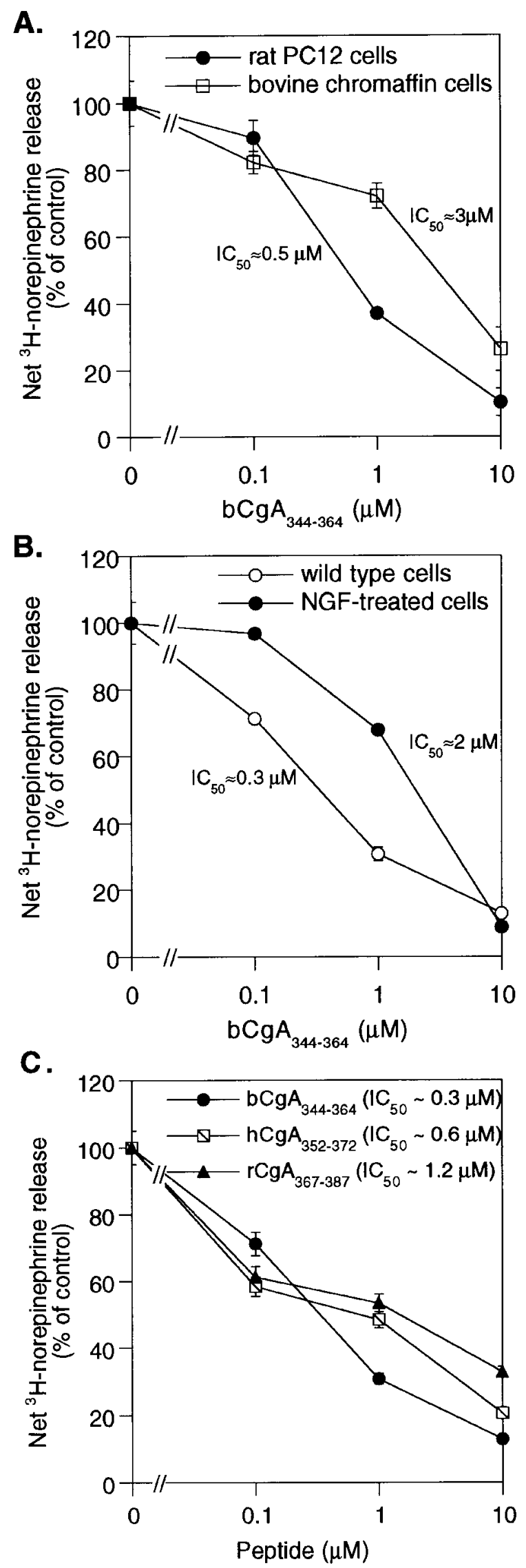

Figure 4. Catestatin effects across species and across catecholaminergic cell types. ( $A$ ) Catestatin (bovine chromogranin $\mathrm{A}_{344-364}$ ) effects
While bovine catestatin completely abolished nicotineinduced uptake of ${ }^{45} \mathrm{Ca}^{2+}$ in PC12 cells, it failed to block ${ }^{45} \mathrm{Ca}^{2+}$ uptake when L-type voltage-gated calcium channels were opened by membrane depolarization (Fig. 5 B).

The influence of bovine catestatin on nicotine-induced rise in intracellular calcium concentration $\left(\left[\mathrm{Ca}^{2+}\right]_{\mathrm{i}}\right)$ was assessed on individual bovine chromaffin cells using the calcium probe Indo-1 (Fig. 5 C). The peak amplitude of the nicotine-evoked $\left[\mathrm{Ca}^{2+}\right]_{\mathrm{i}}$ rise was reduced by $18.5 \%$ from control $(100 \%)$ by $10 \mu \mathrm{M}$ catestatin, and by $36.5 \%$ from control by $50 \mu \mathrm{M}$ catestatin. Furthermore, catestatin at $10 \mu \mathrm{M}$ dose decreased the nicotine-evoked AUC (area under the fluorescence versus time curve) by $53.2 \%$, while $50 \mu \mathrm{M}$ catestatin decreased it by $75 \%$.

Catestatin as a noncompetitive nicotinic cholinergic antagonist. We stimulated PC12 cells with a spectrum of nicotine doses $(10-1,000 \mu \mathrm{M})$, alone or with the following antagonists: hexamethonium $(20 \mu \mathrm{M}$; an established noncompetitive neuronal nicotinic cholinergic antagonist [nicotinic cation channelblocker]), dihydro- $\beta$-erythroidine (DH $\beta E, 20 \mu \mathrm{M}$; an established competitive nicotinic cholinergic antagonist), or bovine catestatin $(10 \mu \mathrm{M})$. Nicotine did not overcome catestatin's inhibition at any dose, functionally establishing catestatin as a noncompetitive nicotinic antagonist (Fig. 6).

We preincubated PC12 cells with bovine catestatin $(10 \mu \mathrm{M})$ or other noncompetitive nicotinic antagonists (procaine, hexamethonium, phencyclidine, or chlorpromazine, each at $10 \mu \mathrm{M}$ ), briefly washed each antagonist off twice, and then stimulated the cells with nicotine $(60 \mu \mathrm{M})$. The nicotinic-inhibitory effects of catestatin, procaine, or hexamethonium were quickly and completely reversed after washout; by contrast, the effects of phencyclidine were only partially reversible, while chlorpromazine effects were entirely unaffected (data not shown).

Catestatin and substance $P$. Since substance $P$ may also have nicotinic cholinergic inhibitory effects on chromaffin cells (53, 54), we compared the inhibitory effects of substance $P$ and bovine catestatin on catecholamine release evoked from PC12 cells by several nicotine doses $(10-1,000 \mu \mathrm{M})$.

on bovine chromaffin cells versus rat PC12 pheochromocytoma cells. $\left[{ }^{3} \mathrm{H}\right] \mathrm{L}$-norepinephrine-prelabeled cells were stimulated with $60 \mu \mathrm{M}$ nicotine for $30 \mathrm{~min}$ in the presence or absence of different doses of bovine catestatin $(0.1-10 \mu \mathrm{M})$. Control $(100 \%)$ net norepinephrine release is that in the presence of nicotine $(60 \mu \mathrm{M})$ stimulation alone, without catestatin. (B) Catestatin (bovine chromogranin $\mathrm{A}_{344-364}$ ) effect on neurite-bearing (nerve growth factor [NGF]-differentiated) $\mathrm{PC} 12$ cells. The neurites were grown by treatment with nerve growth factor $(2.5 \mathrm{~S}$ form, $100 \mathrm{ng} / \mathrm{ml}, 5 \mathrm{~d})$. Cells were then labeled with $\left[{ }^{3} \mathrm{H}\right] \mathrm{L}-$ norepinephrine, and secretion over a 30-min time course was studied in response to $60 \mu \mathrm{M}$ nicotine, either alone or in combination with different doses of bovine catestatin. bCgA, bovine chromogranin A. Control $(100 \%)$ net norepinephrine release is that in the presence of nicotine $(60 \mu \mathrm{M})$ stimulation alone, without catestatin. (C) Effect of several species' synthetic sequences of catestatin on nicotine-induced norepinephrine release. PC12 cells were prelabeled with $\left[{ }^{3} \mathrm{H}\right] \mathrm{L}$-norepinephrine, then treated with $60 \mu \mathrm{M}$ nicotine, either alone or in combination with different doses $(0.1-10 \mu \mathrm{M})$ of bovine (RSMRLSFRARGYGFRGPGLQL), human (SSMKLSFRARAYGFRGPGPQL), or rat (RSMKLSPRARAYGFRDPGPQL) catestatin, and harvested after $30 \mathrm{~min}$ for measurement of norepinephrine secretion. Control (100\%) net norepinephrine release is that in the presence of nicotine $(60 \mu \mathrm{M})$ stimulation alone, without peptide. $\mathrm{bCgA}$, bovine chromogranin $\mathrm{A} ; \mathrm{hCgA}$, human chromogranin $\mathrm{A}$; $\mathrm{rCgA}$, rat chromogranin A. 


\begin{tabular}{|c|c|c|c|}
\hline \multirow[t]{2}{*}{ Species } & \multicolumn{3}{|c|}{ Sequence Conservation } \\
\hline & $\begin{array}{c}\text { dibasic } \\
(\mathrm{KR})\end{array}$ & $\begin{array}{c}\text { active (bovine } \\
\text { chromogranin } A_{344-364} \text { ) }\end{array}$ & $\begin{array}{l}\text { dibasic } \\
\text { (RR) }\end{array}$ \\
\hline Human* & $\ldots \mathrm{KRL}$ & ILSFRARAYGFRGPG & LRRGWR . \\
\hline Human $^{\ddagger}$ & $\ldots \mathrm{KRL}$ & RLSFRARAYGFRGPG & LRRGSR . \\
\hline Bovine $^{\S}$ & $\ldots \mathrm{KRL}$ & RLSFRARGYGFRGPG & LRRGWR. \\
\hline Porcine ${ }^{\|}$ & $\ldots \mathrm{KRL}$ & ILSFRAPAYGFRGPG & LRRGWR . \\
\hline $\mathrm{Rat}^{\mathrm{II}}$ & $\ldots \mathrm{KRL}$ & KLSFRARAYGFRDPG & LRRGWR. \\
\hline \multirow[t]{2}{*}{ Mouse** } & $\ldots \mathrm{KRL}$ & KLSFRTRAYGFRDPG & LRRGWR. \\
\hline & & 2) & $\begin{array}{c}\text { furin } \\
\text { (RXXR) }\end{array}$ \\
\hline
\end{tabular}

*Konecki, D.S., U.M. Benedum, H.H. Gerdes, and W.B. Huttner. 1987. The primary structure of human chromogranin A and pancreastatin. J. Biol. Chem. 262:17026-17030. The catestatin region is human chromogranin $\mathrm{A}_{352-372 .}{ }^{*} \mathrm{Helman}$, L.J., T.G. Ahn, M.A. Levine, A. Allison, P.S. Cohen, M.J. Cooper, D.V. Cohn, and M.A. Israel. 1988. Molecular cloning and primary structure of human chromogranin A (secretory protein I) cDNA. J. Biol. Chem. 263:11559-11563. The catestatin region is human chromogranin $\mathrm{A}_{352-372 .}{ }^{8}$ Iacangelo, A., H.U. Affolter, L.E. Eiden, E. Herbert, and M. Grimes. 1986. Bovine chromogranin A sequence and distribution of its messenger RNA in endocrine tissues. Nature (Lond.) 323:82-86. The catestatin region is bovine chromogranin A $344-364$. IIacangelo, A.L., R. Fischer-Colbrie, K.J. Koller, M.J. Brownstein, and L.E. Eiden. 1988. The sequence of porcine chromogranin A messenger RNA demonstrates chromogranin A can serve as the precursor for the biologically active hormone, pancreastatin. Endocrinology. 122:2339-2341. The catestatin region is porcine chromogranin $\mathrm{A}_{343-363}$. ${ }^{\mathrm{q}}$ Iacangelo, A., H. Okayama, and L.E. Eiden. 1988. Primary structure of rat chromogranin A and distribution of its mRNA. FEBS Lett. 227:115-121. The catestatin region is rat chromogranin $\mathrm{A}_{367-387} * *$ Wu, H.J., D.J. Rozansky, R.J. Parmer, B.M. Gill, and D.T. O'Connor. 1991. Structure and function of the chromogranin A gene. Clues to evolution and tissuespecific expression. J. Biol. Chem. 266:13130-13134. The catestatin region is mouse chromogranin $\mathrm{A}_{364-384}$. A majority of identical residues or conservative substitutions are in bold.

Both catestatin and substance $\mathrm{P}$ showed dose-dependent inhibition of nicotinic-stimulated secretion, and the inhibitory potencies for each peptide were enhanced (i.e., their $\mathrm{IC}_{50}$ values were lower) at higher nicotine doses. Catestatin displayed

Table II. Catestatin Effects on Catecholamine Secretion from PC12 Cells: Dependence on Secretory Stimulation Pathway

\begin{tabular}{|c|c|c|c|}
\hline Pathway & Stimulus & $\begin{array}{l}\text { Catestatin } \\
(10 \mu \mathrm{M})\end{array}$ & $\begin{array}{l}\text { Net }\left[{ }^{3} \mathrm{H}\right] \text { nor- } \\
\text { epinephrine } \\
\text { secretion }\end{array}$ \\
\hline & & & $\%$ \\
\hline \multirow{3}{*}{ Nicotinic cholinergic } & Mock & - & $0 \pm 0.11$ \\
\hline & Nicotine, $60 \mu \mathrm{M}$ & - & $17.2 \pm 0.6$ \\
\hline & " & + & $1.54 \pm 0.08$ \\
\hline \multirow{2}{*}{$\begin{array}{l}\text { Membrane } \\
\text { depolarization }\end{array}$} & $55 \mathrm{mM} \mathrm{KCl}$ & - & $37.0 \pm 1.8$ \\
\hline & " & + & $35.6 \pm 0.61$ \\
\hline \multirow[t]{2}{*}{ Alkaline earth } & $\mathrm{BaCl}_{2}, 2 \mathrm{mM}$ & - & $73.8 \pm 0.44$ \\
\hline & " & + & $75.0 \pm 0.13$ \\
\hline \multirow[t]{2}{*}{ Calcium ionophore } & $\mathrm{A} 23187,1 \mu \mathrm{M}$ & - & $27.4 \pm 0.41$ \\
\hline & " & + & $23.1 \pm 2.06$ \\
\hline \multirow{2}{*}{$\begin{array}{l}\text { Alkalinize } \\
\text { vesicle core }\end{array}$} & Chloroquine, $1 \mathrm{mM}$ & - & $8.79 \pm 0.18$ \\
\hline & " & + & $8.84 \pm 1.20$ \\
\hline \multirow[t]{2}{*}{$\mathrm{P}_{2 \times}$ purinergic } & АТP, $100 \mu \mathrm{M}$ & - & $52.05 \pm 0.09$ \\
\hline & " & + & $51.35 \pm 0.19$ \\
\hline
\end{tabular}

Cells were prelabeled with $\left[{ }^{3} \mathrm{H}\right] \mathrm{L}$-norepinephrine, and were then treated with one of several secretagogues (nicotine [ $60 \mu \mathrm{M}], \mathrm{KCl}$ [55 mM], ATP $[100 \mu \mathrm{M}], \mathrm{BaCl}_{2}[2 \mathrm{mM}], \mathrm{A} 23187[1 \mu \mathrm{M}]$, or chloroquine [1 mM]), either alone or in combination with bovine catestatin $(10 \mu \mathrm{M})$, and harvested after $30 \mathrm{~min}$ for measurement of norepinephrine secretion. The effect of ATP was inhibited (to $39 \%$ ) by the $\mathrm{P}_{2 \times}$ receptor antagonist reactive blue $2(100 \mu \mathrm{M})$. consistently superior molar potency of inhibition to (lower $\mathrm{IC}_{50}$ than) substance $\mathrm{P}$; at the highest nicotine dose $(1,000 \mu \mathrm{M})$, catestatin was $\sim 16$-fold $(2.43 \mu \mathrm{M} / 0.15 \mu \mathrm{M})$ more potent than was substance $\mathrm{P}$ (Fig. 7).

The potent $\left(\mathrm{IC}_{50}=9 \mathrm{nM} ; 40\right)$ substance $P$ antagonist BocGln-D-Trp(CHO)-Phe-OBzl did not reverse bovine catestatin's inhibitory action on nicotinic-stimulated catecholamine release from PC12 cells, even at antagonist doses up to $20 \mu \mathrm{M}$ (data not shown).

\section{Discussion}

The primary structure of chromogranin A in all mammalian species (bovine [11, 12], human [13, 14], rat [15, 49], murine [17], and porcine [16]) contains $8-10$ sites of pairs of basic amino acids (lys or arg), each a potential cleavage site for prohormone processing endoproteases, such as the prohormone convertases (18-20). Proteolysis of chromogranin A takes place both within secretory granules and extracellularly, giving rise to several smaller biologically active peptides such as pancreastatin (which inhibits insulin and parathyroid hormone release [21]), $\beta$-granin or vasostatin (which inhibits parathyroid hormone release and relaxes vascular smooth muscle [22-26]), and parastatin (which inhibits parathyroid hormone release [27]). An emerging functional pattern is that such chromogranin A fragments may inhibit further hormone release from the endocrine cell of origin, perhaps in autocrine, homeostatic (negative feedback) fashion.

Thus, we and others have also searched for chromogranin A fragments that might influence catecholamine release. In 1988, Simon et al. (28) reported that preincubation of chromaffin cells with chromogranin A blunted or abolished their catecholamine secretory response to the usual secretagogue (acetylcholine acting at neuronal nicotinic cholinergic receptors); this observation suggested the presence of an active, cate- 

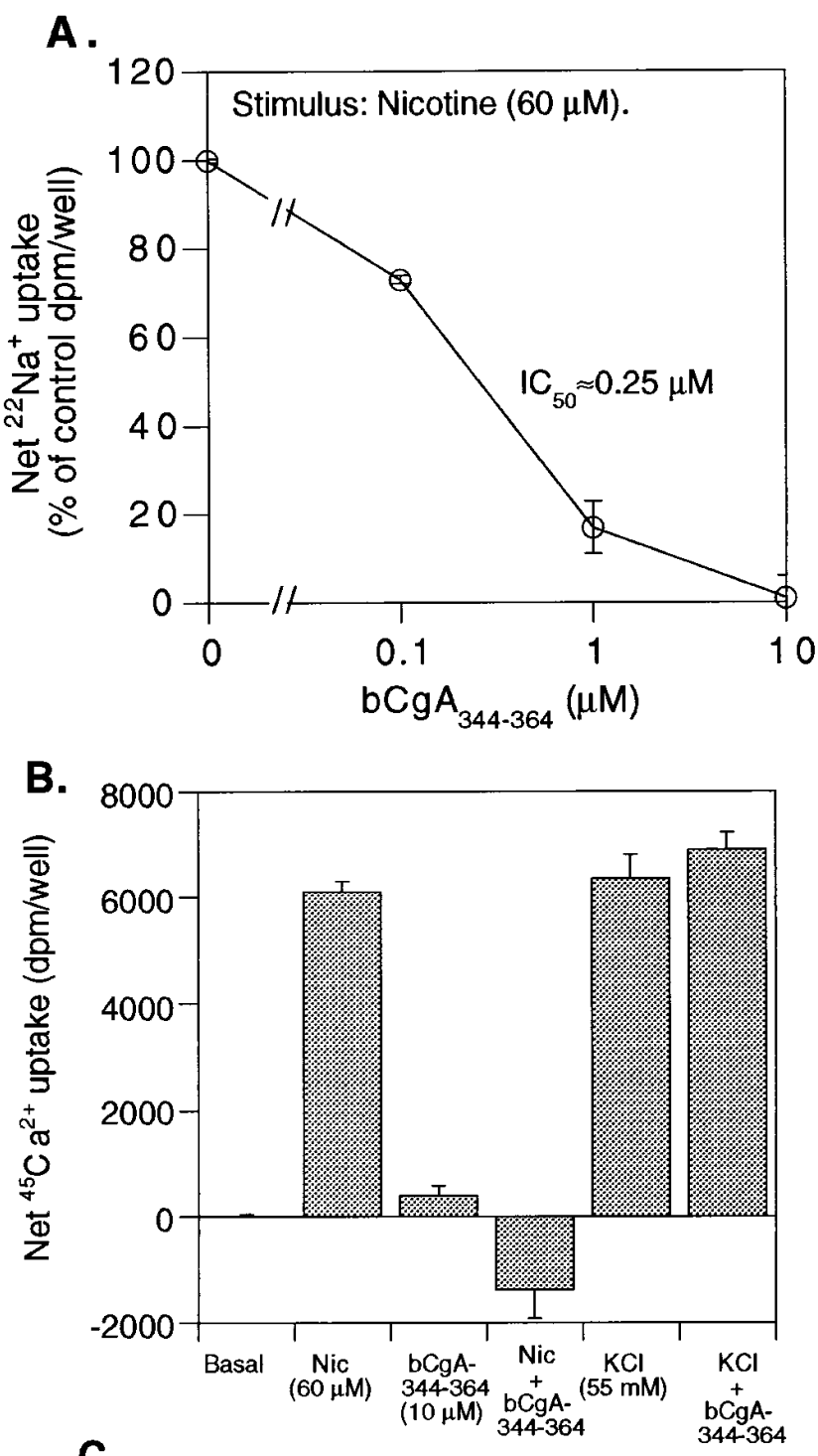

C.

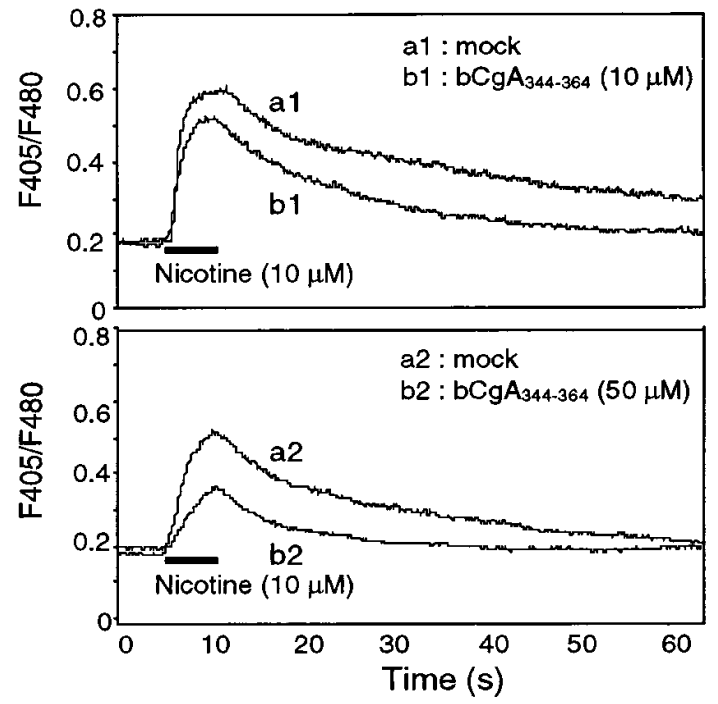

Figure 5. Catestatin and nicotinic cholinergic signal transduction: $\mathrm{Na}^{+}$and $\mathrm{Ca}^{2+}$ cation fluxes. (A) Catestatin (bovine chromogranin $\mathrm{A}_{344-364}$ ) effect on nicotine-induced uptake of ${ }^{22} \mathrm{Na}^{+}$in $\mathrm{PC} 12$ cells. For the ${ }^{22} \mathrm{Na}^{+}$uptake study, cells were treated with ${ }^{22} \mathrm{Na}^{+}$plus nicotine cholamine secretion-inhibiting peptide within the chromogranin A molecule. Thus far, attempts to identify the active peptide $(29,30)$ were frustrated by methodologic artifacts (31).

We found that chromaffin granule core soluble proteins (chromogranins) inhibited chromaffin cell catecholamine release (Fig. 1 B), that low molecular weight (cleaved) chromogranins were a far more potent source of inhibition than were high molecular weight (uncleaved) chromogranins (Fig. $1 B$ ), that chromogranin A itself was a source of such catecholamine secretion-inhibitory fragments (Fig. $1 A$ ), and that the secretion-inhibitory activity was specific for nicotinic stimulation of catecholamine release (Fig. $1 C$ ).

To identify the responsible domain bearing these properties within chromogranin A, we synthesized 15 peptides spanning $78 \%$ of the length of the 431 -amino acid mature protein, and tested their effects on secretion. One of these peptides (bovine chromogranin $\left.\mathrm{A}_{344-364}\right)$ showed potent $\left(\mathrm{IC}_{50} \sim 200 \mathrm{nM}\right)$ antisecretory activity on rat PC12 and bovine chromaffin cells (Figs. $2 A, 3$, and $4 A$ ). An antibody to this region (RSMRLSFRARGYGFRGPGLQL) specifically disrupted the effect of low molecular weight chromogranin fragments on nicotinicstimulated catecholamine secretion (Fig. 2 B), confirming that we had found the specific catecholamine-release inhibitory domain in chromogranin A fragments within and released from chromaffin granules (Fig. 1).

Since this peptide is catecholamine release-inhibitory, we named it catestatin. The catestatin region in bovine chromogranin A (Fig. $2 \mathrm{C}$ ) is bounded on its $\mathrm{NH}_{2}$ and $\mathrm{COOH}$ termini by furin recognition motifs, RXXR (48), and at the $\mathrm{COOH}$ terminus by a dibasic site, RR. The COOH-terminal RR site and RXXR are conserved across all mammalian species (Table I), while the $\mathrm{NH}_{2}$-terminal $\mathrm{RXXR}$ motif is found only in bovine chromogranin $\mathrm{A}$ and in one version of human chromogranin A (14). Of note, emerging evidence from several laboratories (18-20) indicates that chromogranin $\mathrm{A}$ is a substrate for prohormone convertases 1 and 2, as well as furin. By

$(60 \mu \mathrm{M})$, in the presence or absence of bovine catestatin $(0.1-10$ $\mu \mathrm{M}$ ), for $5 \mathrm{~min}$, followed by removal of the medium and cell lysis for measurement of ${ }^{22} \mathrm{Na}^{+}$uptake. Control $(100 \%)$ net ${ }^{22} \mathrm{Na}^{+}$uptake is that in the presence of nicotine $(60 \mu \mathrm{M})$ stimulation alone, without catestatin. Catestatin effects on norepinephrine release (Fig. 3) and ${ }^{22} \mathrm{Na}^{+}$uptake were parallel, with comparable $\mathrm{IC}_{50}$ (molar potency) values. bCgA, bovine chromogranin A. (B) Effect of catestatin (bovine chromogranin $\mathrm{A}_{344-364}$ ) on secretagogue-induced uptake of ${ }^{45} \mathrm{Ca}^{2+}$ from PC12 cells. Cells were treated with ${ }^{45} \mathrm{Ca}^{2+}$ plus nicotine $(60 \mu \mathrm{M})$ or $\mathrm{KCl}(55 \mathrm{mM})$, in the presence or absence of bovine catestatin $(10 \mu \mathrm{M})$ for $1 \mathrm{~min}$, followed by removal of the medium and cell lysis for measurement of ${ }^{45} \mathrm{Ca}^{2+}$ uptake. Nic, nicotine. (C) Effect of catestatin (bovine chromogranin $\mathrm{A}_{344-364}$ ) on $\left[\mathrm{Ca}^{2+}\right]_{\mathrm{i}}$ in bovine chromaffin cells loaded with Indo- 1 . The ratio $\mathrm{F}_{405} / \mathrm{F}_{480}$ measured in individual chromaffin cells was taken as an index of $\left[\mathrm{Ca}^{2+}\right]_{\mathrm{i}}$ variation. Single cells were stimulated with $10 \mu \mathrm{M}$ nicotine for $5 \mathrm{~s}$ (solid bar) in the presence or absence of bovine catestatin, at $10 \mu \mathrm{M}$ (experiment 1; top) or $50 \mu \mathrm{M}$ (experiment 2; bottom). Mean traces resulting from the analysis of 7 (experiment 1 ) or 12 (experiment 2) chromaffin cells were taken from both internal reference cells and catestatin-treated cells for each experiment. Cells were preincubated for $10 \mathrm{~min}$ in Locke's solution containing no catestatin $\left(\mathrm{a}_{1}\right.$ and $\mathrm{a}_{2}$; internal reference controls), $10 \mu \mathrm{M}\left(\mathrm{b}_{1}\right)$, or $50 \mu \mathrm{M}\left(\mathrm{b}_{2}\right)$ catestatin. Cells were then stimulated with $10 \mu \mathrm{M}$ nicotine ( $5 \mathrm{~s}$, solid bar). Similar results were obtained in two separate experiments. 


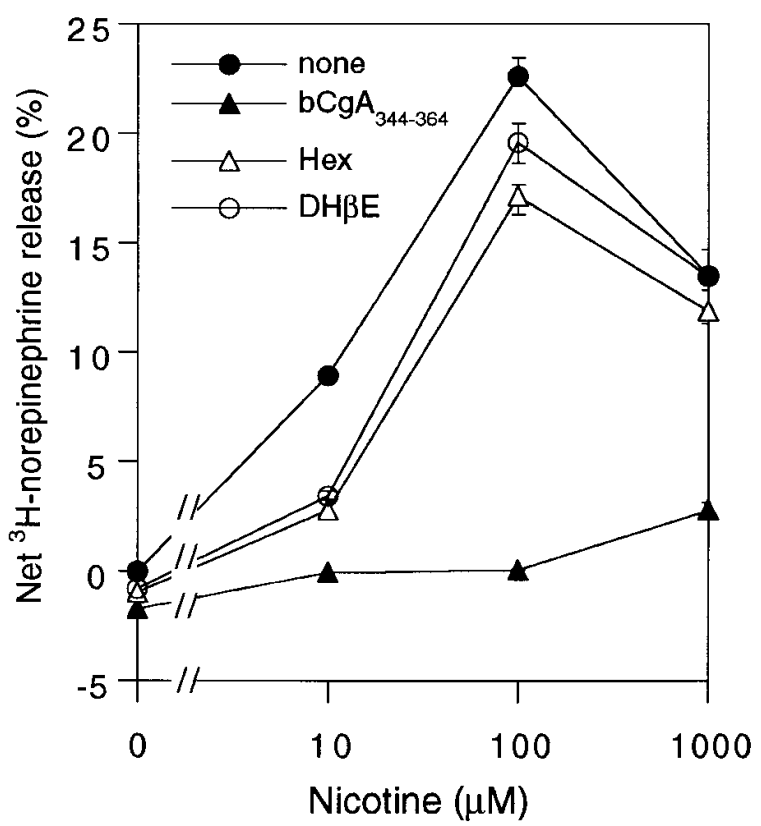

Figure 6. Catestatin as a noncompetitive nicotinic cholinergic antagonist. Inhibition of catecholamine release by a spectrum of concentrations of nicotinic cholinergic antagonists. PC12 cells were labeled with $\left[{ }^{3} \mathrm{H}\right] \mathrm{L}$-norepinephrine, and secretion over a 30-min time course was studied in response to different doses of nicotine $(10-1,000 \mu \mathrm{M})$, either alone or in combination with bovine catestatin (bovine chromogranin $\mathrm{A}_{344-364} ; 10 \mu \mathrm{M}$ ), or positive control neuronal nicotinic antagonists: the noncompetitive nicotinic antagonist (channel blocker) hexamethonium $(20 \mu \mathrm{M})$, or the competitive nicotinic cholinergic antagonist dihydro- $\beta$-erythroidine $(20 \mu \mathrm{M})$. bCgA, bovine chromogranin A; Hex, hexamethonium; DH $\beta E$, dihydro- $\beta$-erythroidine.

immunoblotting, we found that the catestatin region is extensively cleaved from bovine chromogranin A (data not shown); other laboratories $(7,48 \mathrm{a}-\mathrm{c})$ have also documented several proteolytic cleavage sites in this region (Fig. 2 C).

Several species' forms of catestatin (bovine, human, rat) showed similar inhibitory activity (Fig. $4 C$ ), perhaps not surprising in that the sequence of chromogranin $\mathrm{A}$ is well conserved across mammalian species in this region (Table I).

The inhibition of catecholamine release by catestatin was specific for nicotinic cholinergic stimulation, since inhibition did not occur after secretory stimulation by a variety of maneuvers that bypass the nicotinic receptor (Table II), including membrane depolarization, calcium ionophore, or alkalinization of secretory vesicles. PC12 purinergic $\mathrm{P}_{2 \mathrm{x}}$ receptors, which cause secretion in response to ATP (50-52), were not inhibited by catestatin (Table II). Since $\mathrm{P}_{2 \mathrm{x}}$ receptors are members of the same family of extracellular ligand-gated cation channels as nicotinic cholinergic receptors (52), the specificity of catestatin inhibitory effects within this receptor family is apparent.

Catestatin effects on chromaffin cell signal transduction are also consistent with a specific inhibitory action on nicotinic cholinergic signaling. As predicted for a nicotinic antagonist, catestatin blocked nicotinic-stimulated $\mathrm{Na}^{+}$entry into the cytosol, and blockade of $\mathrm{Na}^{+}$entry (Fig. $5 \mathrm{~A}$ ) paralleled blockade of catecholamine secretion (Fig. 3). In addition, catestatin blocked entry of $\mathrm{Ca}^{2+}$ from the extracellular space into the cytosol (Fig. 5, $B$ and $C$ ), but only when such entry was triggered by nicotinic stimulation, and not when triggered by membrane depolarization (Fig. $5 \mathrm{~B}$ ), which opens calcium channels at a signal transduction step distal to nicotinic stimulation (55).

The inability of nicotine to overcome catestatin's secretory inhibition even at very high nicotine doses (Fig. 6) is consistent with noncompetitive nicotinic inhibition, though we do not yet know the precise site at which catestatin interacts with the nicotinic receptor. Rapid and complete reversibility of catestatin's secretory inhibition weighs against the possibility that very tight binding of catestatin to the agonist-binding site of the nicotinic receptor might prevent nicotine from overcoming the antagonism at high nicotine dose. Lack of effect of pertussis toxin (33) on the inhibition weighs against an indirect effect of catestatin on nicotinic function.

Why is catestatin's $\mathrm{IC}_{50}$ for nicotinic inhibition different on untreated versus neurite-bearing PC12 cells (Fig. $4 B$ ), or on (rat) PC12 versus bovine chromaffin cells (Fig. $4 A$ )? Perhaps reported differences or changes in nicotinic receptor subunit composition or stoichiometry in these models are important (56-58). Since nerve growth factor-treated PC12 cells may not be completely equivalent to noradrenergic neurons, we have not yet conclusively shown a catestatin effect upon such nerves. Among other biologically active chromogranin A fragments, pancreastatin may display peculiar differences in activity when used across species; indeed, porcine pancreastatin may be more effective at inhibiting insulin release from the rat pancreas than from the pig pancreas (59).

Although both catestatin and substance $P$ inhibit nicotinic cholinergic-stimulated catecholamine release (Fig. 7), catestatin displays consistently higher molar potency (lower $\mathrm{IC}_{50}$ ) than

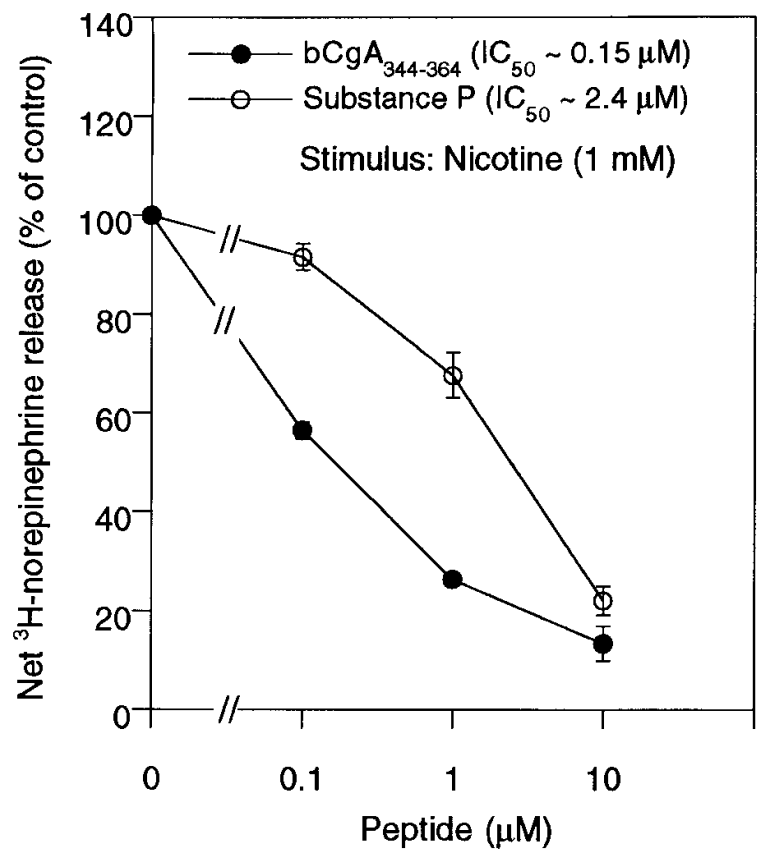

Figure 7. Effects of the neuropeptide substance $\mathrm{P}$ on nicotinic cholinergic-stimulated catecholamine release from PC12 cells. PC12 cells were prelabeled with $\left[{ }^{3} \mathrm{H}\right] \mathrm{L}$-norepinephrine, and secretion over 30 min was studied in response to $1 \mathrm{mM}$ nicotine, in the presence or absence of substance P (RPKPQQFFGLM-amide; $0.1-10 \mu \mathrm{M}$ ), or bovine catestatin (bovine chromogranin $\mathrm{A}_{344-364} ; 0.1-10 \mu \mathrm{M}$ ). bCgA, bovine chromogranin A. 


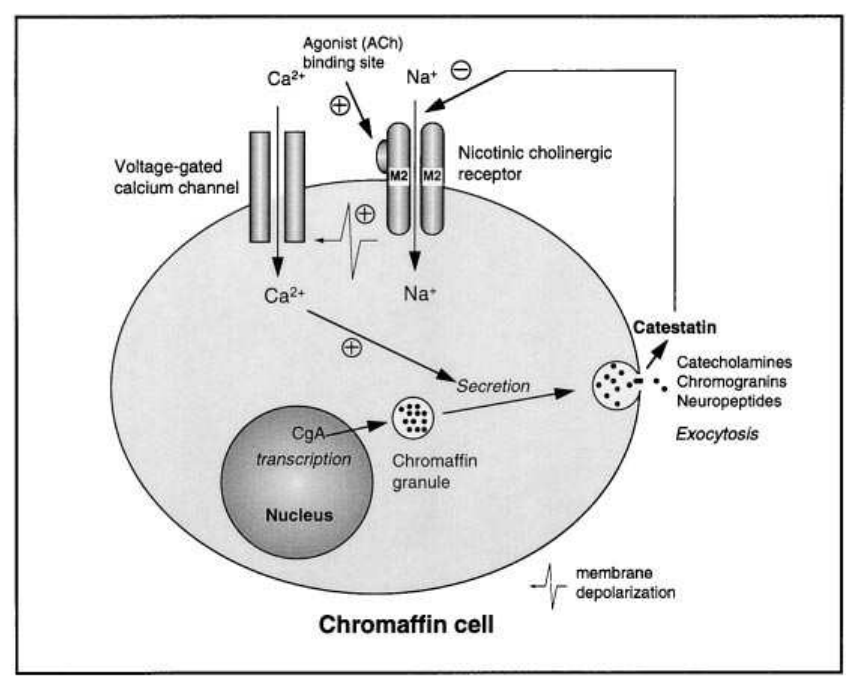

Figure 8. Model for the action of the chromogranin A fragment catestatin on catecholamine secretion from chromaffin cells. The physiologic secretagogue for chromaffin cells is acetylcholine, acting at neuronal type nicotinic cholinergic receptors. Such receptors are extracellular ligand-gated cation channels, permitting cytosolic influx of sodium, which depolarizes the cell membrane, permitting cytosolic influx of calcium through voltage-gated calcium channels. Antagonists at nicotinic receptors may be either competitive (with the agonist binding site), or noncompetitive (often cation channel blockers). $\mathrm{CgA}$, chromogranin A; Ach, acetylcholine; M2, cation channel domain of the nicotinic cholinergic receptor.

does substance P. Lack of reversal of catestatin's inhibitory effect by the potent substance $\mathrm{P}$ antagonist Boc-Gln-D$\operatorname{Trp}(\mathrm{CHO})$-Phe-OBzl (40) argues against mediation of the catestatin effect by the classical substance $\mathrm{P}\left(\mathrm{NK}_{1}\right)$ receptor; indeed, substance P's inhibitory effects on catecholamine release may also be at least partially resistant to $\mathrm{NK}_{1}$ receptor blockade (60), and are similarly likely to result from a direct interaction of substance $\mathrm{P}$ with the nicotinic cholinergic receptor (54). A direct physical interaction of substance $\mathrm{P}$ with the Torpedo nicotinic cholinergic receptor has been documented by photoaffinity cross-linking (61).

It should be noted that the catestatin region (Fig. $2 C$ ) of chromogranin A (bovine chromogranin $\mathrm{A}_{344-364}$; porcine chromogranin $A_{343-363}$ ) overlaps the parastatin region of chromogranin $\mathrm{A}$, originally described as a porcine chromogranin $\mathrm{A}$ fragment (chromogranin $\mathrm{A}_{347-419}$ ) capable of inhibiting parathyroid hormone release from parathyroid chief cells (27). At this time, we do not know precisely which chromogranin A amino acids in this region are crucial for these two very different biological functions. Since parathyroid hormone is released in response to extracellular calcium concentration sensed by a heptahelical, G protein-linked receptor (62), the catestatin and parastatin domains may interact with very different receptor targets.

Is an $\mathrm{IC}_{50}$ of $\sim 200 \mathrm{nM}$ for catestatin likely to be physiologically meaningful? The concentration of chromogranin $\mathrm{A}$ in chromaffin granules is $\sim 200 \mathrm{mg} / \mathrm{ml}(63)$, or $\sim 4 \mathrm{mM}(11,12)$. Just after exocytosis, the concentration of chromaffin granule core contents in the extracellular space in the vicinity of the exocytotic pore is $\sim 10$-fold lower than it is in the granule (64). Thus, a chromogranin A concentration of $\sim 0.4 \mathrm{mM}$ is likely in the local extracellular space just after exocytosis. Hence, an $\mathrm{IC}_{50}$ of $\sim 200 \mathrm{nM}$ is quite likely to be meaningful in vivo.

In conclusion, a small 21-amino acid oligopeptide domain within chromogranin A (chromogranin $\mathrm{A}_{344-364}$ ) is a potent $\left(\mathrm{IC}_{50} \sim 200 \mathrm{nM}\right)$ inhibitor of chromaffin cell and sympathetic neurite catecholamine release. This domain's primary structure is conserved across mammalian species, is flanked by proteolytic cleavage sites, and is processed from chromogranin A in chromaffin granules. The inhibition is selective for the physiologic (nicotinic cholinergic agonist) stimulus to chromaffin cell secretion, and thus reproduces the inhibitory pattern found in crude chromaffin granule fractions. At the nicotinic receptor, the inhibition is noncompetitive with agonist. The inhibition specifically impairs nicotinic cationic $\left(\mathrm{Ca}^{2+}\right.$ and $\left.\mathrm{Na}^{+}\right)$ signal transduction. This inhibitory peptide may represent a novel, autocrine homeostatic (negative-feedback) mechanism controlling catecholamine release from chromaffin cells and noradrenergic neurons (Fig. 8).

\section{References}

1. Blaschko, H., R.S. Comline, F.H. Schneider, M. Silver, and A.D. Smith. 1967. Secretion of a chromaffin granule protein, chromogranin, from the adrenal gland after splanchnic stimulation. Nature (Lond.). 215:58-59.

2. Schneider, F.H., A.D. Smith, and H. Winkler. 1967. Secretion from the adrenal medulla: biochemical evidence for exocytosis. Br. J. Pharmacol. Chemother. 31:94-104.

3. Winkler, H., and R. Fischer-Colbrie. 1992. The chromogranins A and B: the first 25 years and future perspectives. Neuroscience. 49:497-528.

4. Huttner, W.B., H.H. Gerdes, and P. Rosa. 1991. Chromogranins/secretogranins-widespread constituents of the secretory granule matrix in endocrine cells and neurons. In Markers for Neural and Endocrine cells. M. Gratzl and K. Langley, editors. VCH Verlagsgesellschaft mbH, Weinheim, Germany. 93-131.

5. O’Connor, D.T., and L.J. Deftos. 1986. Secretion of chromogranin A by peptide producing endocrine neoplasms. N. Engl. J. Med. 314:1145-1151.

6. Parmer, R.J., X.-P. Xi, H.J. Wu, L.J. Helman, and L.N. Petz. 1993. Secretory protein traffic: chromogranin A contains a dominant targeting signal for the regulated pathway. J. Clin. Invest. 92:1042-1054.

7. Metz-Boutigue, M.-H., P. Garcia-Sablone, R. Hogue-Angeletti, and D. Aunis. 1993. Intracellular and extracellular processing of chromogranin A: Determination of cleavage sites. Eur. J. Biochem. 217:247-257.

8. Helle, K.B., G. Serck-Hanssen, and S. Aardal. 1993. Functional aspects of the adrenal medullary chromogranins. Neurochem. Int. 22:353-360.

9. Dillen, L., B. Miserez, M. Claeys, D. Aunis, and W. DePotter. 1993. Posttranslational processing of proenkephalins and chromogranins/secretogranins. Neurochem. Int. 22:315-352.

10. Parmer, R.J., L.A. Miles, X.-P. Xi, B.M. Gill, H. Wu, and D.T. O'Connor. 1993. Processing of chromaffin granule proteins: a profusion of proteases? Neurochem. Int. 22:361-367.

11. Benedum, U.M., P.A. Baeuerle, D.S. Konecki, R. Frank, J. Powell, J. Mallet, and W.B. Huttner. 1986. The primary structure of bovine chromogranin A: a representative of a class of acidic secretory proteins common to a variety of peptidergic cells. EMBO J. 5:1495-1502.

12. Iacangelo, A., H.U. Affolter, L.E. Eiden, E. Herbert, and M. Grimes. 1986. Bovine chromogranin A sequence and distribution of its messenger RNA in endocrine tissues. Nature (Lond.). 323:82-86.

13. Konecki, D.S., U.M. Benedum, H.H. Gerdes, and W.B. Huttner. 1987. The primary structure of human chromogranin A and pancreastatin. J. Biol. Chem. 262:17026-17030.

14. Helman, L.J., T.G. Ahn, M.A. Levine, A. Allison, P.S. Cohen, M.J. Cooper, D.V. Cohn, and M.A. Israel. 1988. Molecular cloning and primary structure of human chromogranin A (secretory protein I) cDNA. J. Biol. Chem. 263:11559-11563.

15. Iacangelo, A., H. Okayama, and L.E. Eiden. 1988. Primary structure of rat chromogranin A and distribution of its mRNA. FEBS Lett. 227:115-121.

16. Iacangelo, A.L., R. Fischer-Colbrie, K.J. Koller, M.J. Brownstein, and L.E. Eiden. 1988. The sequence of porcine chromogranin A messenger RNA demonstrates chromogranin A can serve as the precursor for the biologically active hormone, pancreastatin. Endocrinology. 122:2339-2341.

17. Wu, H.J., D.J. Rozansky, R.J. Parmer, B.M. Gill, and D.T. O'Connor. 1991. Structure and function of the chromogranin A gene. Clues to evolution and tissue-specific expression. J. Biol. Chem. 266:13130-13134.

18. Eskeland, N.L., A. Zhou, T.Q. Dinh, H. Wu, R.J. Parmer, R.E. Mains, and D.T. O'Connor. 1996. Chromogranin A processing and secretion. Specific 
role of endogenous and exogenous prohormone convertases in the regulated secretory pathway. J. Clin. Invest. 98:148-156.

19. Arden, S.D., N.G. Rutherford, P.C. Guest, W.J. Curry, E.M. Bailyes, C.F. Johnston, and J.C. Hutton. 1994. The post-translational processing of chromogranin A in the pancreatic islet: involvement of the eukaryote subtilisin PC2. Biochem. J. 298:521-528.

20. Hoflehner, J., U. Eder, A. Laslop, N.G. Seidah, R. Fischer-Colbrie, and H. Winkler. 1995. Processing of secretogranin II by prohormone convertases: importance of PC1 in generation of secretoneurin. FEBS Lett.360:294-298.

21. Tatemoto, K., S. Efendic, V. Mutt, G. Makk, G.J. Feistner, and J.D. Barchas. 1986. Pancreastatin, a novel pancreatic peptide that inhibits insulin secretion. Nature (Lond.). 324:476-478.

22. Hutton, J.C., H.W. Davidson, K.A. Grimaldi, and M. Peshavaria. 1987. Biosynthesis of beta-granin in pancreatic (beta)-cells. Biochem. J. 244: 449-456.

23. Drees, B.M., J. Rouse, J. Johnson, and J.W. Hamilton. 1991. Bovine parathyroid glands secrete a $26-\mathrm{kDa}$ N-terminal fragment of chromogranin A which inhibits parathyroid cell secretion. Endocrinology. 129:3381-3387.

24. Drees, B.M., and J.W. Hamilton. 1994. Processing of chromogranin A by bovine parathyroid secretory granules: production and secretion of $\mathrm{N}$-terminal fragments. Endocrinology. 134:2057-2063.

25. Aardal, S., and K.B. Helle. 1992. The vasoinhibitory activity of bovine chromogranin A fragment (vasostatin) and its independence of extracellular calcium in isolated segments of human blood vessels. Regul. Pept. 41:9-18.

26. Helle, K.B., P.D. Marley, R. Hogue-Angeletti, D. Aunis, E. Galindo, D.H. Small, and B.G. Livett. 1993. Chromogranin A: secretion of processed products from the stimulated retrogradely perfused bovine adrenal gland. $J$. Neuroendocrinol. 5:413-420.

27. Fasciotto, B.H., C.A. Trauss, G.H. Greeley, and D.V. Cohn. 1993. Parastatin (porcine chromogranin $\mathrm{A}_{347-419}$ ), a novel chromogranin A-derived peptide, inhibits parathyroid cell secretion. Endocrinology. 133:461-466.

28. Simon, J.-P., M.-F. Bader, and D. Aunis. 1988. Secretion from chromaffin cells is controlled by chromogranin A-derived peptides. Proc. Natl. Acad. Sci. USA. 85:1712-1716.

29. Galindo, E., A. Rill, M.-F. Bader, and D. Aunis. 1991. Chromostatin, a 20-amino acid peptide derived from chromogranin A, inhibits chromaffin cell secretion. Proc. Natl. Acad. Sci. USA. 88:1426-1430.

30. Galindo, E., M. Mendez, S. Calvo, C. Gonzalez-Garcia, V. Cena, P. Hubert, M.-F. Bader, and D. Aunis. 1992. Chromostatin receptors control calcium channel activity in adrenal chromaffin cells. J. Biol. Chem. 267:407-412.

31. Galindo, E., A. Rill, M.-F. Bader, and D. Aunis. 1994. Chromostatin, a 20-amino acid peptide derived from chromogranin A, inhibits chromaffin cell secretion. Proc. Natl. Acad. Sci. USA. 91:832 (correction to Proc. Natl. Acad. Sci. USA. 1991. 88:1426-1430).

32. Greene, L.A., and A.S. Tischler. 1976. Establishment of a noradrenergic clonal cell line of rat adrenal pheochromocytoma cells which respond to a nerve growth factor. Proc. Natl. Acad. Sci. USA. 73:2424-2428.

33. Milligan, G. 1988. Techniques used in the identification and analysis of function of pertussis toxin-sensitive guanine nucleotide binding proteins. Biochem. J. 255:1-13.

34. Bader, M.-F., D. Thierse, D. Aunis, G. Ahnert-Hilger, and M. Gratzl. 1986. Characterization of hormone and protein release from alpha-toxin-permeabilized chromaffin cells in primary culture. J. Biol. Chem. 261:5777-5783.

35. Mahata, M., S.K. Mahata, R.J. Parmer, and D.T. O'Connor. 1996. Vesicular monoamine transport inhibitors. Novel action at calcium channels to prevent catecholamine secretion. Hypertension (Dallas). 28:414-420.

36. Smith, A.D., and H. Winkler. 1967. Purification and properties of an acidic protein from chromaffin granules of bovine adrenal medulla. Biochem. J. 103:483-492.

37. Syversen, U., H.L. Waldum, and D.T. O'Connor. 1992. Rapid, highyield isolation of human chromogranin A from chromaffin granules of pheochromocytomas. Neuropeptides. 22:235-240.

38. Bradford, M.M. 1976. A rapid and sensitive method for the quantitation of microgram quantities of protein utilizing the principle of protein-dye binding. Anal. Biochem. 7:248-254.

39. Merrifield, R.B. 1963. Solid phase peptide synthesis. I. The synthesis of a tetrapeptide. J. Am. Chem. Soc. 85:2149-2154.

40. Hagiwara, D., H. Miyake, H. Morimoto, M. Masako, T. Fujii, and M. Matsuo. 1992. Studies on neurokinin antagonists. 1. The design of novel tripeptides possessing the glutaminyl-D-tryptophylphenylalanine sequence as substance P antagonists. J. Med. Chem. 35:2015-2025.

41. Barbosa, J.A., B.M. Gill, M.A. Takiyyuddin, and D.T. O'Connor. 1991. Chromogranin A: posttranslational modifications in secretory granules. Endocrinology. 128:174-190.

42. Gill, B.M., J.A. Barbosa, R. Hogue-Angeletti, N. Varki, and D.T. O'Connor. 1992. Chromogranin A epitopes: clues from synthetic peptides and peptide mapping. Neuropeptides. 21:105-108.

43. O'Connor, D.T., R.P. Frigon, and R.L. Sokoloff. 1984. Human chromogranin A. Purification and characterization from catecholamine storage ves- icles of human pheochromocytoma. Hypertension (Dallas). 6:2-12.

44. Amy, C., and N. Kirshner. 1982. ${ }^{22} \mathrm{Na}^{+}$uptake and catecholamine secretion by primary cultures of adrenal medulla cells. J. Neurochem. 39:132-142.

45. Pandol, S.J., M.S. Schoeffield, C.J. Fimmel, and S. Muallem. 1987. The agonist-sensitive calcium pool in the pancreatic acinar cell: activation of plasma membrane $\mathrm{Ca}^{2+}$ influx mechanism. J. Biol. Chem. 262:16963-16968.

46. Taupenot, L., J. Ciesielski-Treska, G. Ulrich, S. Chasserot-Golaz, D. Aunis, and M.-F. Bader. 1996. Chromogranin A triggers a phenotypic transformation and the generation of nitric oxide in brain microglial cells. Neuroscience. 72:377-389.

47. O'Connor, D.T., and R.P. Frigon. 1984. Chromogranin A, the major catecholamine storage vesicle soluble protein: multiple size forms, subcellular storage and regional distribution in chromaffin and nervous tissue elucidated by radioimmunoassay. J. Biol. Chem. 259:3237-3247.

48. Molloy, S.S., P.A. Bresnahan, K. Klimpel, L. Leppla, and G. Thomas. 1992. Human furin is a calcium-dependent serine endoprotease that recognizes the sequence Arg-X-X-Arg and efficiently cleaves anthrax toxin protective antigen. J. Biol. Chem. 267:16396-16402.

48a. Curry, W.J., C. Shaw, C.F. Johnston, L. Thim, and K.D. Buchanan. 1992. Isolation and primary structure of a novel chromogranin A-derived peptide, WE14, from a human midgut carcinoid tumour. FEBS Lett. 30:319-321.

48b. Kirchmair, R., B. Leitner, R. Fischer-Colbrie, J. Marksteiner, R. Hogue-Angeletti, and H. Winkler. 1995. Large variations in the proteolytic formation of a chromogranin A-derived peptide (GE-25) in neuroendocrine tissues. Biochem. J. 310:331-336.

48c. Sigafoos, J., W.G. Chestnut, B.M. Merrill, L.C. Taylor, E.J. Diliberto, Jr., and O.H. Viveros. 1993. Novel peptides from adrenomedullary chromaffin vesicles. J. Anat. 183:253-264.

49. Parmer, R.J., A.H. Koop, M.T. Handa, and D.T. O'Connor. 1989. Molecular cloning of chromogranin A from rat pheochromocytoma cells. Hypertension (Dallas.). 14:435-444.

50. Inoue, K., K. Nakazawa, M. Ohara-Imaizumi, T. Obama, K. Fujimori, and A. Takanaka. 1991. Antagonism by reactive blue 2 but not by brilliant blue $\mathrm{G}$ of extracellular ATP-evoked responses in PC12 phaeochromocytoma cells. Br. J. Pharmacol. 102:851-854.

51. Lin, L.F., M.C. Bott, L.-S. Kao, and E.W. Westhead. 1995. ATP stimulated catecholamine secretion: response in perfused adrenal glands and a subpopulation of cultured chromaffin cells. Neurosci. Lett. 183:147-150.

52. Conley, E.C. 1996. The Ion Channel FactsBook. I. Extracellular LigandGated Channels. Academic Press, Inc., San Diego. 426 pg.

53. Cheung, N.S., P. Karlsson, J.X. Wang, M. Bienert, P. Oehme, and B.G. Livett. 1994. Functional studies with substance $\mathrm{P}$ analogues: effects of $\mathrm{N}$-terminal, C-terminal, and C-terminus-extended analogues of substance $\mathrm{P}$ on nicotine-induced secretion and desensitization in cultured bovine adrenal chromaffin cells. J. Neurochem. 62(6):2246-2253.

54. Livett, B.G., and P.D. Marley. 1993. Noncholinergic control of adrenal catecholamine secretion. J. Anat. 183(pt. 2):277-289.

55. Kirshner, N. 1987. Sodium and calcium channels in cultured bovine adrenal medulla cells. In Stimulus-Secretion Coupling in Chromaffin Cells, Volume II. K. Rosenheck and P.I. Lelkes, editors. CRC Press, Boca Raton, FL. 71-86.

56. McLane, K.E., X.D. Wu, and B.M. Conti-Tronconi. 1990. Identification of a brain acetylcholine receptor alpha subunit able to bind alpha-bungarotoxin. J. Biol. Chem. 265:9816-9824.

57. Madhok. T.C., and B.M. Sharp. 1992. Nerve growth factor enhances $\left[{ }^{3} \mathrm{H}\right]$ nicotine binding to a nicotinic cholinergic receptor on PC12 cells. Endocrinology. 130:825-830.

58. Rogers, S.W., A. Mandelzys, E.S. Deneris, C. Cooper, and S. Heinemann. 1992. The expression of nicotinic acetylcholine receptors by PC12 cells treated with NGF. J. Neurosci. 12:4611-4623.

59. Holst, J.J., C.G. Ostenson, H. Harling, and T. Messell. 1990. Porcine pancreastatin has no effect on endocrine secretion from the pig pancreas. Diabetologia 33(7):403-406.

60. Khalil, Z., P.D. Marley, and B.G. Livett. 1988. Effect of substance P on nicotine-induced desensitization of cultured bovine adrenal chromaffin cells: possible receptor subtypes. Brain Res. 459(2):282-288.

61. Blanton, M.P., Y.M. Li, E.R. Stimson, J.E. Maggio, and J.B. Cohen. 1994. Agonist-induced photoincorporation of a p-benzoylphenylalanine derivative of substance $\mathrm{P}$ into membrane-spanning region 2 of the Torpedo nicotinic acetylcholine receptor delta subunit. Mol. Pharmacol. 46(6):1048-1055.

62. Chattopadhyay, N., A. Mithal, and E.M. Brown. 1996. The calciumsensing receptor: a window into the physiology and pathophysiology of mineral ion metabolism. Endocr. Rev. 17(4):289-307.

63. Winkler, H., D.K. Apps, and R. Fischer-Colbrie. 1986. The molecular function of adrenal chromaffin granules: established facts and unresolved topics. Neuroscience. 18:261-290.

64. Wightman, R.M. 1995. Kinetics of catecholamine release during exocytosis. International Symposium on Chromaffin Cell Biology, 8th, Edinburgh S-25:66. 